\title{
Historical and paleo-tsunami deposits during the last 4000 years and their correlations with historical tsunami events in Koyadori on the Sanriku Coast, northeastern Japan
}

\author{
Daisuke Ishimura $^{1 *}$ and Takahiro Miyauchi ${ }^{2}$
}

\begin{abstract}
Large tsunamis occurring throughout the past several hundred years along the Sanriku Coast on the Pacific coast of northeastern Japan have been documented and observed. However, the risk of large tsunamis like the tsunami generated by the 2011 off the Pacific coast of Tohoku earthquake could not be evaluated from previous studies, because these studies lacked evidence of historical and paleo-tsunami deposits on the coastline. Thus, we first identified event deposits, which are candidates for tsunami deposits, from excavating surveys conducted on the coastal marsh in Koyadori on the Sanriku Coast, northeastern Japan. Second, we determined the physicochemical sediment properties of the deposits (roundness of grains, color, wet and dry densities, and loss on ignition) and established their geochronology by radiocarbon dating and tephra analysis. Third, we identified event deposits as tsunami deposits, based on their sedimentary features and origin, sedimentary environment, paleo-shoreline, and landowner interviews. In this study, we report 11 tsunami deposits (E1-E11) during the past 4000 years, of which E1, E2, E3, and E4 were correlated with the 2011 Tohoku-oki tsunami, the 1896 Meiji Sanriku tsunami, the 1611 Keicho Sanriku tsunami, and the 869 Jogan tsunami, respectively. From age data and the number of tsunami deposits in the trench, we estimated that tsunamis larger than the 1896 Meiji Sanriku tsunami occur and hit the study area on average every 290-390 years. However, historical tsunami correlations revealed variable tsunami occurrence, indicating diverse tsunami generation and/or the combination of several types of large earthquakes from different sources around the Japan Trench.
\end{abstract}

Keywords: Historical and paleo-tsunami deposits; Sanriku Coast; 2011 Tohoku-oki tsunami; Historical tsunami correlation; Geochronology

\section{Background}

Historical and paleo-tsunami research and its application to geophysical study

The 2011 off the Pacific coast of Tohoku earthquake (2011 Tohoku-oki earthquake) $\left(M_{\mathrm{w}}\right.$ 9.0) that occurred on March 11, 2011, triggered a large tsunami (2011 Tohoku-oki tsunami) along the east coast of Japan, causing

\footnotetext{
* Correspondence: ishimura@irides.tohoku.ac.jp

'Disaster Science Division, International Research Institute of Disaster Science, Tohoku University, 468-1 Aza-aoba, Aramaki, Aoba-ku, Sendai, Miyagi 980-0845, Japan

Full list of author information is available at the end of the article
}

severe damage and loss of life. The Pacific coastal region, in particular, the Sanriku Coast (Fig. 1), ranks among the highest tsunami risk areas in Japan, in terms of both severity and frequency (Watanabe 1998). However, we could not assess the risk of large tsunamis like the 2011 Tohoku-oki tsunami because we lack sufficient knowledge about large earthquakes and the tsunami history in the Japan Trench. Even after the 2011 Tohoku-oki tsunami, the long-term tsunami history of the Sanriku Coast remains obscured by inadequate field data (Sugawara et al. 2012). Moreover, the geological and geophysical problems revealed by the 2011 Tohoku-oki earthquake, 


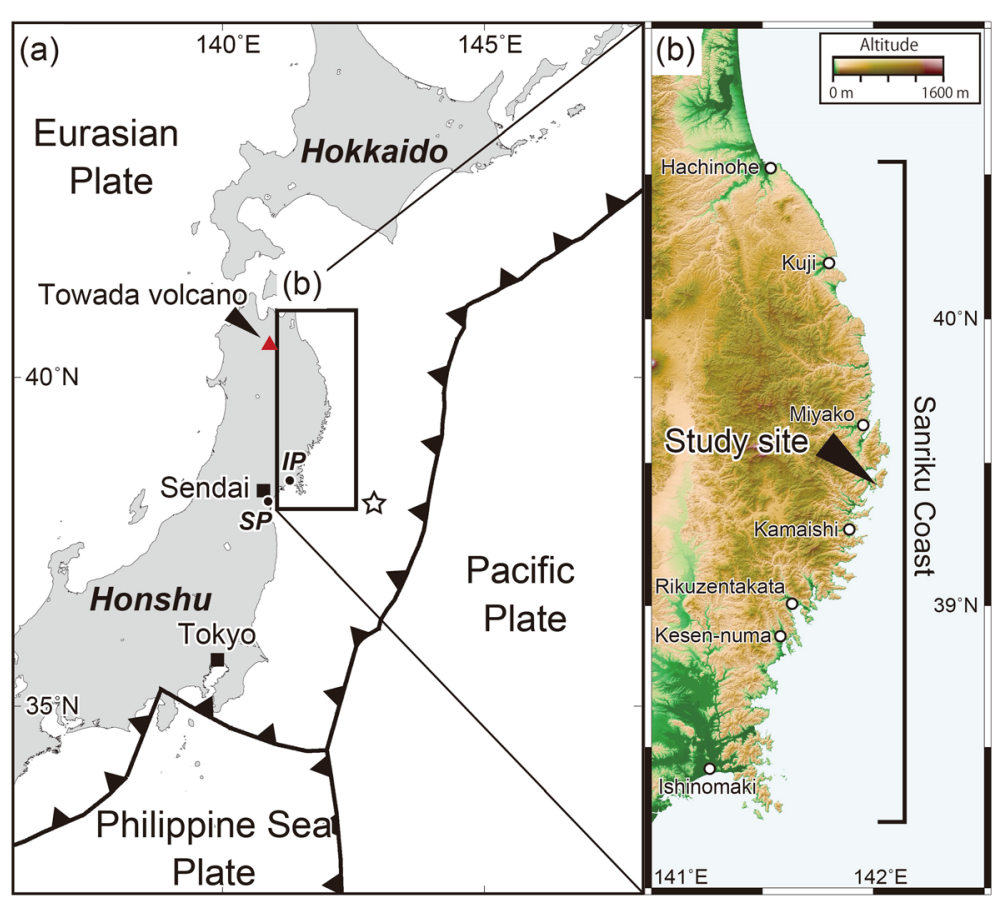

Fig. 1 Study site location. a Plate tectonic map in and around northeastern Japan. The star indicates the epicenter location of the 2011 Tohoku-oki earthquake determined by the Japan Meteorological Agency. SP Sendai Plain, IP Ishinomaki Plain. b Study area and geomorphology along the Sanriku Coast

including mechanisms of tsunami generation (Kawamura et al. 2012; Tappin et al. 2014) and large earthquakes (Ikeda et al. 2012; Goldfinger et al. 2013; Rajendran 2013), remain unsolved. Recent studies have suggested that submarine mass failure (e.g., submarine landslide) may have contributed to large tsunamis along the Japan Trench (Kawamura et al. 2012; 2014; Tappin et al. 2014). To resolve these problems, we require long-term solid evidence (e.g., historical and paleo-tsunami deposits).

The best sources of precise long-term tsunami data are coastal lowlands, in particular, marshes (Minoura and Nakaya 1991; Witter et al. 2003; Sawai et al. 2009; Shennan et al. 2014). In some regions (Hokkaido of Japan, Alaska of USA, and the North Island of New Zealand), coseismic and post-seismic crustal movements are recorded in sediments as lithological and biological changes (Witter et al. 2003; Sawai and Nasu 2005; Hamilton and Shennan 2005; Hayward et al. 2005). Thus, in this study, we excavated trenches at a coastal marsh in Koyadori, in the middle part of the Sanriku Coast (Fig. 1). The aim was to provide new geological evidence of historical and paleo-tsunami deposits.

\section{Study site}

Koyadori is located in the central part of the Sanriku Coast, the easternmost part of Honshu Island (Figs. 1 and 2). Approximately $200 \mathrm{~km}$ east of Koyadori, the Pacific plate subducts underneath the Eurasian Plate, where rupture areas of historical and observed earthquakes have been identified on the plate boundary (Earthquake Research Committee
Headquarters for Earthquake Research Promotion Prime Minister's Office, Government of Japan 1999). In Koyadori, the mouth of the valley is closed by beach ridges. Prior to the 2011 Tohoku-oki tsunami, which hit the valley (Fig. 3), the study site was used as paddy fields.

The geology differs on both sides of the valley (Fig. 2; Yoshida et al. 1984). The east side comprises Early Cretaceous hornblende-biotite granodiorite, granite, granite porphyry, and tonalite. The west side comprises dacite to rhyolite lava and pyroclastic rock deposited during the Early Cretaceous. Ishimura et al. (2014) drilled cores at the study site (Fig. 4), revealing visible tephra layers such as the Towada-Chuseri tephra (To-Cu: $6 \mathrm{ka}$; Machida and Arai 2003) and Oguni Pumice (7.3-7.4 ka; Ishimura et al. 2014) erupted from the Towada Volcano (Fig. 1).

\section{Tsunami history and previous study of tsunami deposits}

Large historical earthquakes and tsunamis have been instrumentally recorded during the last several decades and have been recorded in historical documents and legends during the last 1300 years (Utsu 2004). Many earthquakegenerated tsunamis have hit the areas around Koyadori (Table 1), nine of which were large events with runup heights exceeding a few meters (Table 2). The 2011 Tohoku-oki tsunami exhibits the largest runup height measured between AD 2011 and 1896. In contrast, based on the estimated runup heights, the largest tsunami occurring between AD 1611 and 1856 was probably the 1611 Keicho Sanriku tsunami (Table 2). Candidates of 


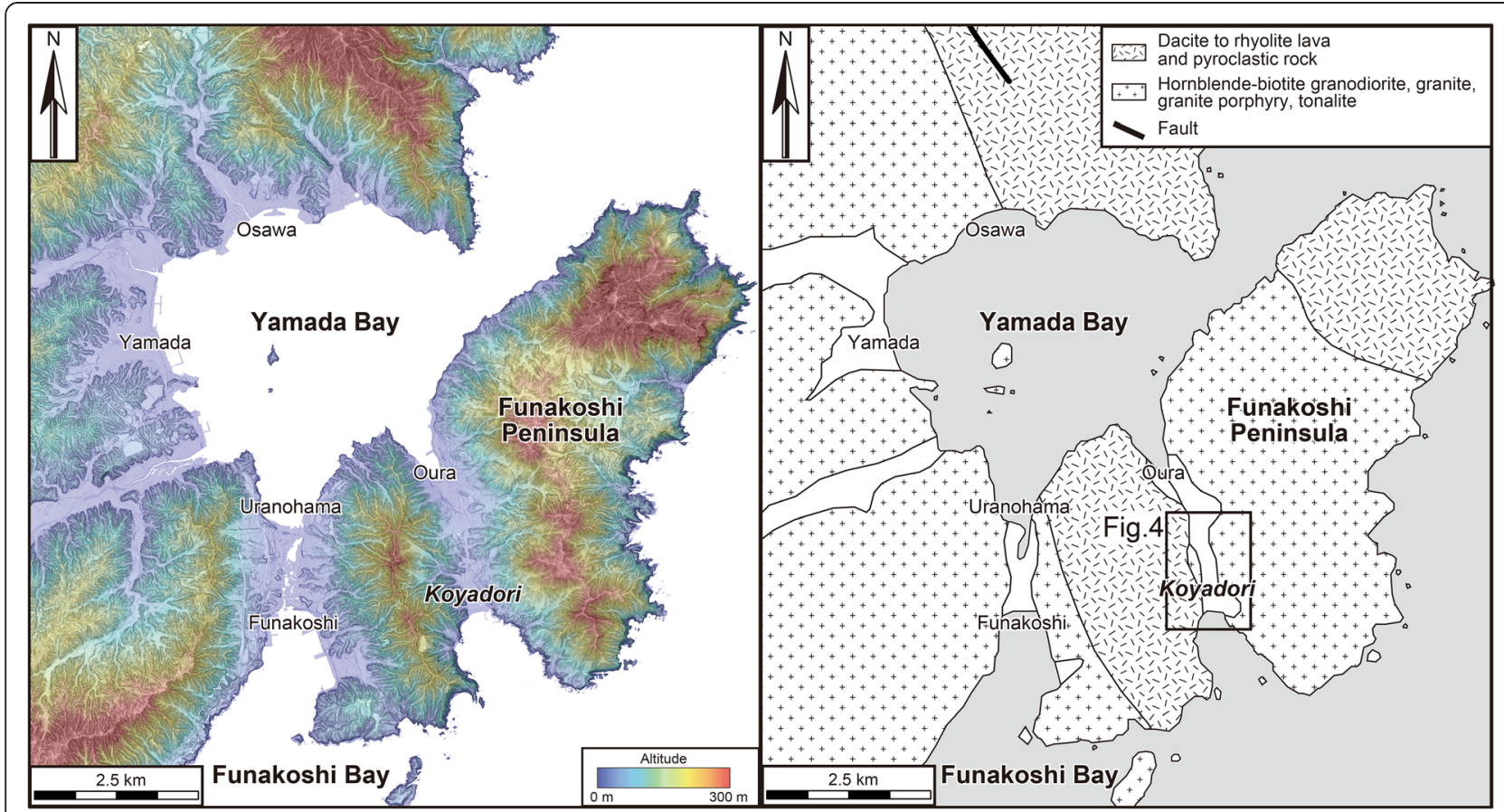

Fig. 2 Topography and geology around the Funakoshi Peninsula. Base map is based on the 5 m mesh DEM supplied by the Geospatial Information Authority of Japan. Geology is modified after Yoshida et al. (1984)

historical tsunamis older than AD 1611 are the 869 Jogan tsunami and the 1454 Kyotoku tsunami. The 869 Jogan tsunami, identified in the Sendai and Ishinomaki Plains (Fig. 1) (Minoura and Nakaya 1991; Minoura et al. 2001; Sawai et al. 2007; Shishikura et al. 2007), has been noted as the penultimate large tsunami event around these plains (after the 2011 Tohoku-oki earthquake and tsunami), because its inundation in the Sendai Plain was similar to that of the 2011 Tohoku-oki tsunami (Sugawara et al. 2012; Namegaya and Satake 2014). However, the northern and southern distribution limits of the 869 Jogan tsunami deposits have not yet been determined (Sugawara et al. 2012). Thus, elucidating whether the 869 Jogan tsunami reached the Sanriku Coast is essential for tsunami risk assessment and seismological study. Consequently, this information is urgently required (Sugawara et al. 2012). If the 869 Jogan tsunami and 2011 Tohoku-oki tsunami were of similar severity, a large tsunami is also likely to have struck the areas along the Sanriku Coast in AD 869. In recent times, the 1454 Kyotoku tsunami has been identified from tsunami deposits in the Sendai and Ishinomaki Plains (Sawai et al. 2012) and historical documents (Namegaya and Yata 2014). However, at our study site, information on the Kyotoku tsunami deposits and the size of the tsunami has not yet been obtained.

Historical and paleo-tsunami deposits along the Sanriku Coast have been studied at several sites by
The Headquarters for Earthquake Research Promotion (2006; 2007; 2008; 2009; and 2010), Haraguchi et al. (2006a, b; 2007), Haraguchi and Goya (2007), Imaizumi et al. (2007), Torii et al. (2007), and Haraguchi and Ishibe (2009) before the 2011 event. However, historical tsunami deposits were identified at only one of the onshore sites at Rikuzentakata (Fig. 1). This site has revealed four historical tsunami deposits during the past 700 years, the latest of which was correlated with the 1960 Chile tsunami (The Headquarters for Earthquake Research Promotion 2007). The other events are not well correlated with historical tsunamis. Recent sediments, in particular, those deposited during the past 1000 to 2000 years, are badly preserved at other onshore sites (Torii et al. 2007; The Headquarters for Earthquake Research Promotion 2010). Therefore, historical tsunami deposits are poorly understood along the Sanriku Coast.

\section{Methods}

\section{Geomorphological classification}

Initial mapping of geomorphic surfaces around Koyadori was based on interpretation of 1:8000- and 1:10,000-scale aerial photographs taken by the Geospatial Information Authority of Japan before and after the 2011 Tohoku-oki tsunami, and anaglyph images prepared from $1 \mathrm{~m}$ and $5 \mathrm{~m}$ mesh DEM (Digital Elevation Model) provided by the Geospatial Information Authority of Japan and the Iwate Prefecture. 


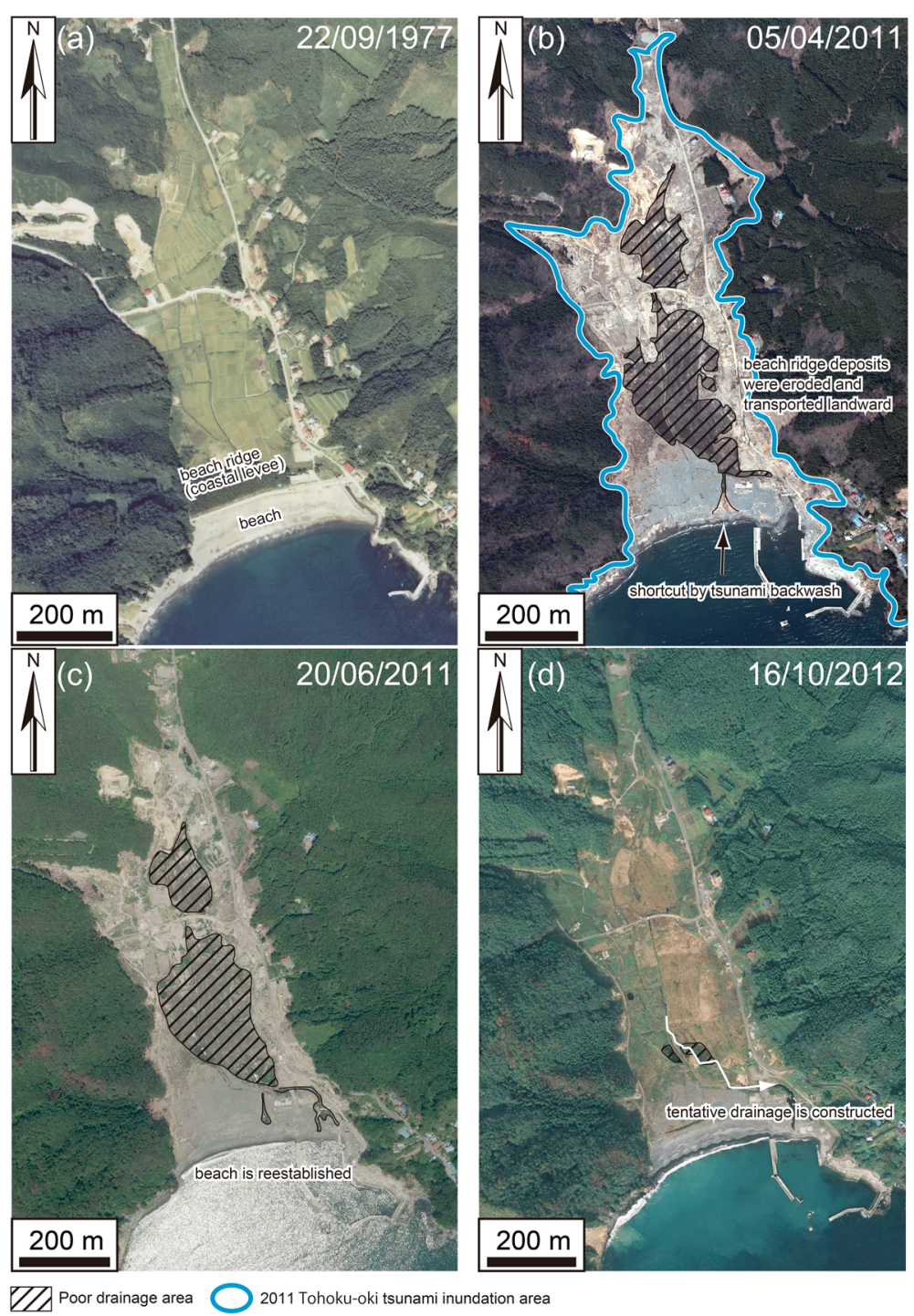

Fig. 3 Aerial photographs around Koyadori before and after the 2011 Tohoku-oki earthquake. Aerial photos (a)-(d) were taken on September 1977, March 2011, June 2011, and October 2012, respectively, by the Geospatial Information Authority of Japan

\section{Trench survey}

In December 2012, we excavated a $12 \mathrm{~m}$ long, $3 \mathrm{~m}$ wide, and $2 \mathrm{~m}$ deep trench (KYD-trench) approximately $3 \mathrm{~m}$ above sea level (a.s.l.) and $300 \mathrm{~m}$ distant from the shoreline (Figs. 4 and 5a, b). We logged and took photographs of each trench wall. Block samples $(50 \mathrm{~cm}$ long, $10 \mathrm{~cm}$ wide, and $5 \mathrm{~cm}$ deep) were taken from the west, east, and south walls. The block samples of the west wall overlapped, while those of the other walls were separate (Fig. 6). We also sampled deposits of each event from the east wall for particle roundness analysis (Fig. 6). In 2013, a construction company excavated an additional canal (the canal-trench; approximate length, width, and depth 300,1 , and $0.5 \mathrm{~m}$, respectively) as a tentative drainage for field restoration (Fig. 4). To confirm the continuity of each event, we logged a $150 \mathrm{~m}$-long section of the canal-trench wall and sampled sediments for particle roundness analysis.

\section{Dry and wet density, color, and loss on ignition} measurement

We sampled the entire $7 \mathrm{~cm}^{3}$ cube (each side $=2.2 \mathrm{~cm}$ ) from the block samples and measured their wet and dry bulk densities. The color of wet sediments in cubic samples is quantified by the $\mathrm{L}^{*}, \mathrm{a}^{*}$, and $\mathrm{b}^{*}$ parameters measured by the Soil Color Reader SPAD-503 instrument (Konica Minolta Sensing, Inc.). The $\mathrm{a}^{*}$ and $\mathrm{b}^{*}$ parameters specify the red $(+)$ to green $(-)$ and yellow $(+)$ to blue $(-)$ content, respectively, while $L^{*}$ represents lightness $(0=$ black, $100=$ white). The loss on ignition (LOI) was conducted in each block sample following Bos et al. (2012) at 3-6 cm 

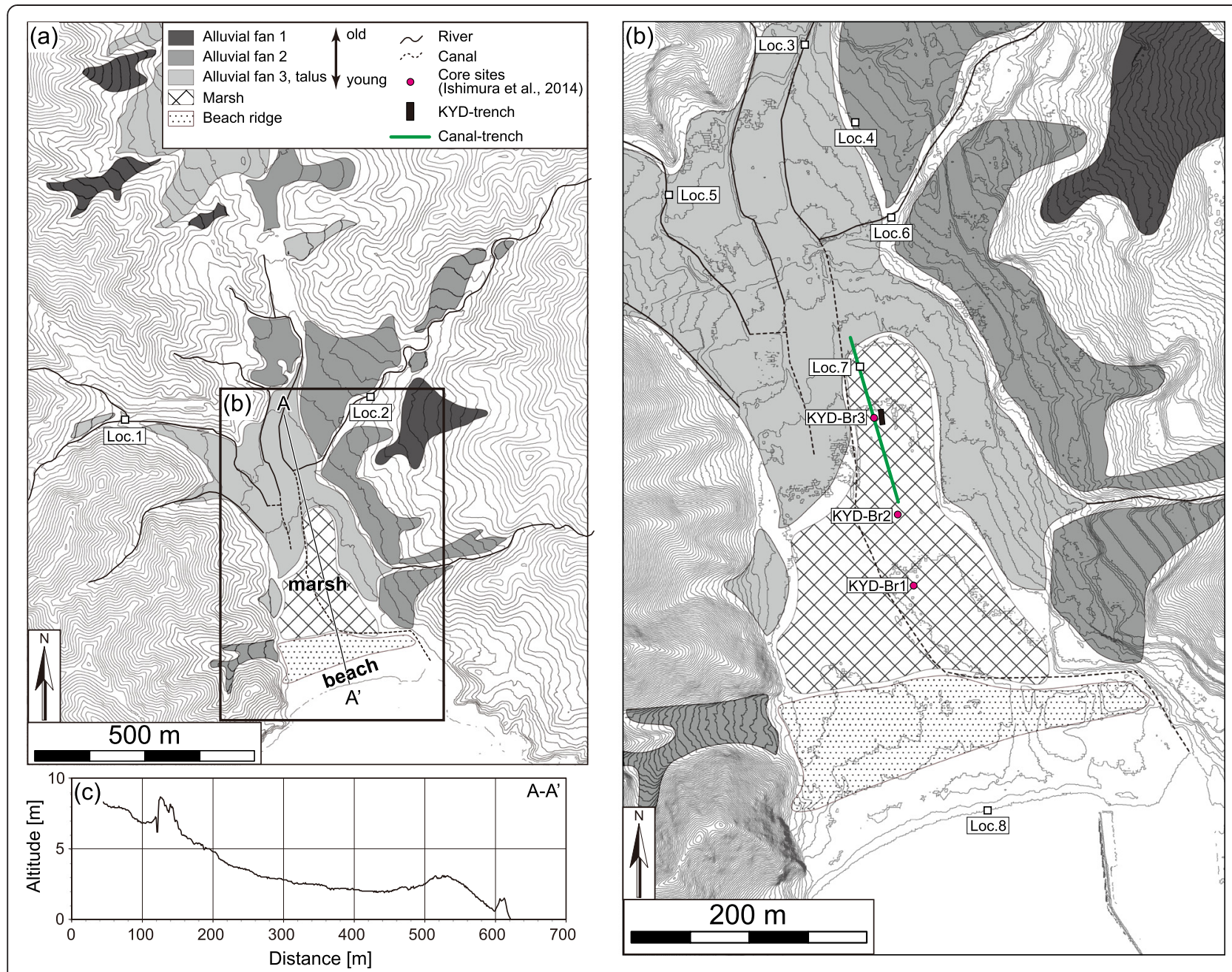

Fig. 4 Geomorphological classification around Koyadori. Contour maps are based on the $1 \mathrm{~m}$ mesh DEM supplied by the Iwate Prefecture. The contour interval in (a) and (b) is $5 \mathrm{~m}$ and $1 \mathrm{~m}$, respectively. c Topographic profile along $\mathrm{A}-\mathrm{A}^{\prime}$ line based on the $1 \mathrm{~m} \mathrm{mesh}$ DEM

intervals, although this sampling was restricted to peat and peaty silt.

\section{Particle roundness}

Furthermore, to reveal the origins of the event deposits and to confirm tsunami deposits, we sampled fluvial and beach sediments (Locations 1-8) (Fig. 4) for particle roundness analysis in 2012 and 2013. Samples were washed and dry-sieved through $2 \mathrm{~mm}$ mesh and the gravels were divided into six roundness categories (very angular, angular, sub-angular, sub-rounded, rounded, and well-rounded).

\section{Radiocarbon dating}

Radiocarbon dating (30 samples) was conducted by accelerator mass spectroscopy (AMS) at the Institute of Accelerator Analysis Ltd. and Geo Science Laboratory. The obtained age data were calibrated using the OxCal 4.2 program (Ramsey 2009) and the calibration curve IntCal13 (Reimer et al. 2013).

\section{Tephra analysis}

The Towada-a tephra (To-a) (AD915; Machida and Arai 2003) is a useful indicator of the 869 Jogan tsunami deposits in the Sendai and Ishinomaki Plains (Minoura and Nakaya 1991; Sawai et al. 2007; Shishikura et al. 2007). From the presence and distribution of To-a along the southern Sanriku Coast, Ishimura et al. (2014) suggested that To-a had also been deposited at the central Sanriku Coast. Therefore, we conducted a cryptotephra analysis to identify the invisible To-a horizon.

Each block sample was sampled at 3-6 cm intervals. These samples were washed using $60 \mu \mathrm{m}$ nylon mesh and dry-sieved using $124 \mu \mathrm{m}$ nylon mesh. Thin sections made with the 60-124 $\mu \mathrm{m}$ fractions revealed volcanic glass contents. The refractive index of volcanic glass shards, which is useful for identifying widespread tephras in Japan 
Table 1 Historical tsunamis along the Sanriku Coast during AD 1611-2011

\begin{tabular}{|c|c|c|c|c|}
\hline Date & Name & Latitude $\left[{ }^{\circ} \mathrm{N}\right]$ & Longitude $\left[{ }^{\circ} \mathrm{E}\right]$ & Magnitude \\
\hline \multicolumn{5}{|c|}{ Earthquakes in observed records (after 1896) } \\
\hline 11 March 2011 & Tohoku-oki & 38.1 & 142.86 & 9.0 \\
\hline 26 September 2003 & Tokachi-oki & 41.78 & 144.08 & 8.0 \\
\hline 16 May 1968 & Tokachi-oki & 40.73 & 143.58 & 7.9 \\
\hline 23 May 1960 & Chile & -38.17 & -72.57 & 9.5 \\
\hline 4 March 1952 & Tokachi-oki & 41.8 & 144.13 & 8.2 \\
\hline 3 November 1936 & Miyagiken-oki & 38.26 & 142.07 & 7.5 \\
\hline 3 March 1933 & Showa Sanriku & 39.23 & 144.52 & 8.1 \\
\hline 1 November 1915 & Miyagiken-oki & 38.3 & 142.9 & 7.5 \\
\hline 5 August 1897 & Miyagkeni-oki & 38.3 & 143.3 & 7.7 \\
\hline 15 June 1896 & Meiji Sanriku & 39.5 & 144 & 8.2 \\
\hline \multicolumn{5}{|c|}{ Earthquakes in documented records (before 1896) } \\
\hline 23 August 1856 & Ansei & 41 & 142.3 & 7.7 \\
\hline 17 February 1793 & Kansei & 38.5 & 144.5 & 8.2 \\
\hline 29 January 1763 & Horeki & 41 & 142.5 & 7.7 \\
\hline 13 April 1677 & Empo & 41 & 143 & 7.9 \\
\hline 2 December 1611 & Keicho & 39 & 144 & 8.1 \\
\hline
\end{tabular}

Based on Utsu (2004). We selected major earthquakes generating tsunamis hitting the Sanriku Coast

(Machida and Arai 2003), was measured with a refractive index measuring system (RIMS 2000: Kyoto Fission Track Co., Ltd.). The RIMS system measures volcanic glass shards to an accuracy of \pm 0.0002 (Danhara et al. 1992). The major element compositions were analyzed by energy-dispersive spectrometry using an electron probe microanalysis (EPMA) system (Horiba Emax Energy EX-250) at the FURUSAWA Geological Survey. The major elements were measured by scanning a $4 \mu \mathrm{m}$ grid of the targeted grain under a counting time of $150 \mathrm{~s}$ and accelerating voltage of $15 \mathrm{kV}$. The beam current and diameter were $0.3 \mathrm{nA}$ and $150 \mathrm{~nm}$, respectively. The atomic number effect was corrected by the ZAF procedure.

\section{Results}

2011 Tohoku-oki tsunami and its deposits

The inundation and runup heights of the 2011 Tohoku-oki tsunami at Koyadori ranged from 13 to $18 \mathrm{~m}$ a.s.l. and

Table 2 Historical tsunamis' runup height around Koyadori

\begin{tabular}{|c|c|c|c|c|c|c|c|c|}
\hline Tsunami event & Age [AD] & Koyadori [m] & Oura [m] & Funakoshi [m] & Uranohama [m] & Yamada $[\mathrm{m}]$ & Osawa [m] & References \\
\hline \multicolumn{9}{|c|}{ Measured runup height } \\
\hline Tohoku-oki & 2011 & $26.0-29.4$ & $7.7-11.3$ & $13.5-16.1$ & $13.6-14.9$ & $8.7-10.4$ & $5.8-8.9$ & $\begin{array}{l}\text { Haraguchi and Iwamatsu } \\
\text { (2011) }\end{array}$ \\
\hline Tokachi-oki & 1968 & & & 3.3 & & 1.1 & 0.7 & Watanabe (1998) \\
\hline Chile & 1960 & No inundation ${ }^{a}$ & & $3.5-4.4$ & & 3.5 & 4.0 & Iwate Prefecture (1969) \\
\hline Showa Sanriku & 1933 & 6.6 & $1.2-4.2$ & $3.7-5.0$ & 3.0 & $3.0-4.0$ & $1.1-2.5$ & $\begin{array}{l}\text { Earthquake Research Institute, } \\
\text { the University of Tokyo (1934) }\end{array}$ \\
\hline Meiji Sanriku & 1896 & 15.0 & 6.0 & $10.0-12.0$ & & 6.0 & 5.5 & Unohana and Ota (1988) \\
\hline \multicolumn{9}{|c|}{ Estimated runup height based on historical documents } \\
\hline Ansei & 1856 & 3 & 2 & $4-6$ & & 2 & 3 & $\begin{array}{l}\text { Tsuji and Ueda (1995), } \\
\text { Hatori (2000) }\end{array}$ \\
\hline Kansei & 1793 & & 2 & $3-4$ & & $2-3$ & 2 & Hatori (2009) \\
\hline Empo & 1677 & & & & & $2-4$ & & $\begin{array}{l}\text { Hatori (1975), Tsuji and } \\
\text { Ueda (1995), }\end{array}$ \\
\hline Keicho & 1611 & $20-25$ & & $10-12$ & & $5-8$ & & Hatori (2009) \\
\hline
\end{tabular}




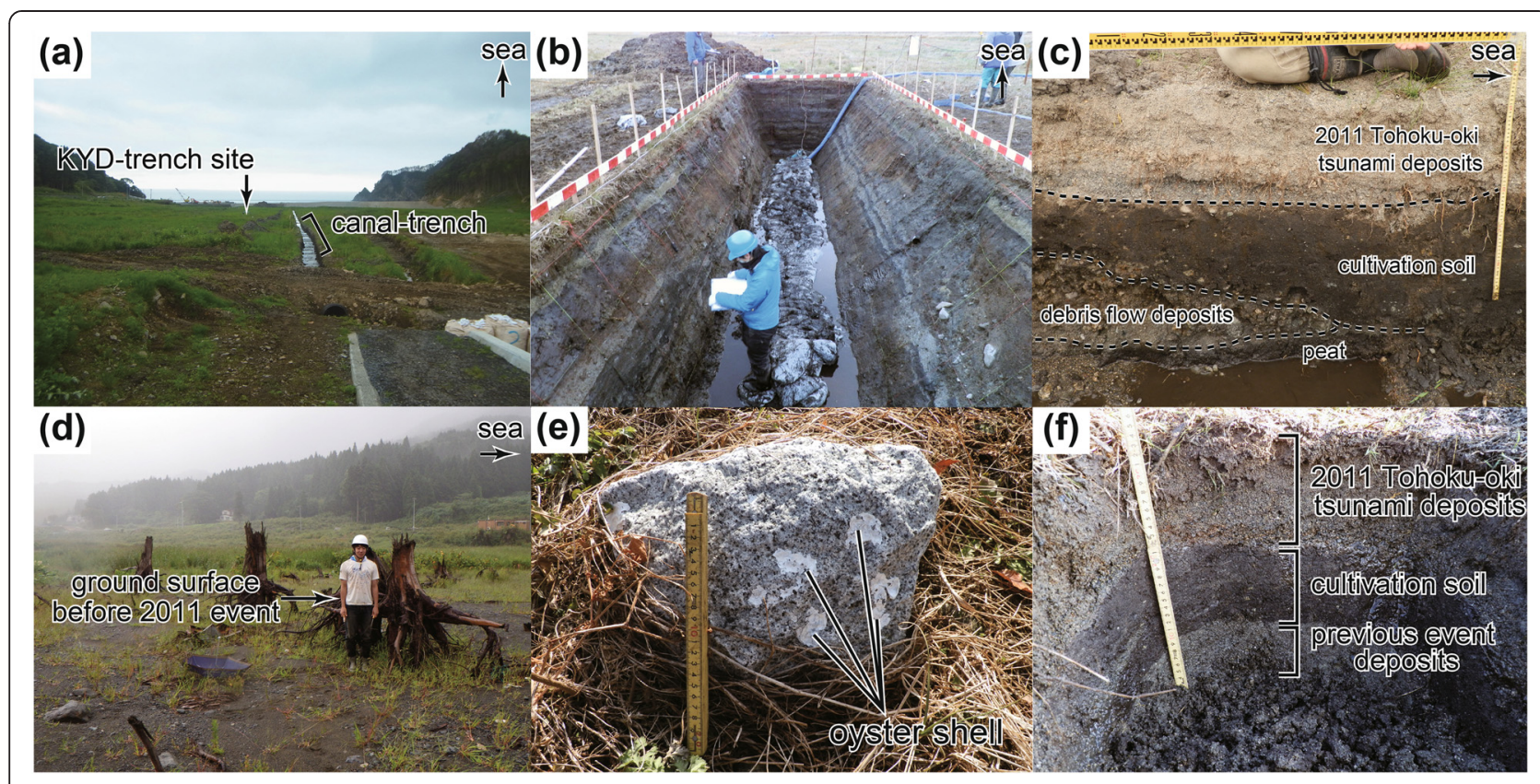

Fig. 5 Photographs around the trench sites. a The KYD- and canal-trench sites, $\mathbf{b}$ the KYD-trench, $\mathbf{c}$ the canal-trench, $\mathbf{d}$ erosion of beach ridges, e tsunami boulder, and $\mathbf{f} 2011$ tsunami deposits

from 26 to 29 m a.s.l., respectively (Table 2; Haraguchi and Iwamatsu 2011). Figure 3 shows the landform changes before and after the 2011 event. Immediately following the 2011 Tohoku-oki tsunami (April 2011), the beach was not yet re-established and the beach ridges may have been shortened by the tsunami backwash (Fig. 3a, b). After the beach was restored in June 2011, the shortcut channel was filled with beach deposits (Fig. 3c). The poor drainage area remained until October 2012 (Fig. 3d). The Tohoku-oki tsunami hit the coastal levee originating from beach ridges, destroying it and the trees on it, and eroding it to a depth of 1-1.5 m (Fig. $5 \mathrm{~d}$ ). The eroded materials were transported landward and deposited as tsunami deposits. Approximately $9 \mathrm{~m}$ a.s.l. and $600 \mathrm{~m}$ landward, a boulder was recognizable as a tsunami deposit because of the attached oyster shells (Fig. 5e). Tsunami deposits composed of sand and gravel sourced from the beach and beach ridges were found up to $600 \mathrm{~m}$ landward in December 2012 (Fig. 5f).

\section{Description of the KYD-trench}

Deposits in the trench wall were divided into five facies (event deposits, marsh deposits, channel fill deposits, artificial fill deposits, and cultivation soil), based on their sediment structure, continuity, and composition (Fig. 6). All the walls contained marsh deposits and interbedded event deposits.

The event deposits are composed of coarse sand and granule, and are traceable in the trench (Figs. 6 and 7). Deposits showing good continuity, horizontal sedimentation, erosional features, and loading structure at the base were considered as potential candidates for tsunami deposits, and were labeled E1 (youngest) to E11 (oldest). The characteristics of each event deposit are presented in Table 3. The E1 deposits (the 2011 Tohoku-oki tsunami deposits) are divisible into two units. The lower unit is composed of coarse sediments (pebble to coarse sand) with normal grading. The upper unit comprises finer sediments (granule to medium sand) and is partially laminated. The E2 deposits are thin and composed of granule to coarse sand. The E2 layer is interbedded with cultivation soil, indicating partial disturbance by cultivation. The E3 deposits are well traceable and characterized by a bluish color (Fig. 6). As these deposits thicken from grids E-3 to S-3, they also become coarser (cobble to pebble). However, while the basal contact is very sharp, the upper contact is partially disturbed by cultivation. The E4 deposits are partially disturbed and eroded by channel deposits. In general, their compositions are fine (granule to fine sand), although some parts contain pebble to cobble gravels. The E5 deposits are interbedded with low-LOI organic sediments (Fig. 7). Their basal contact is sharp, but their upper contact is disturbed. They are intermittently distributed because of plant bioturbation. The E6 deposits are well traceable in the KYD-trench (Fig. 6), with very sharp basal contacts and a loading structure at the bottom of the layer. The E7 deposits are also well traceable and some of them have eroded the E8 deposits (Fig. 6). The E7 layer also shows a loading structure at the bottom. The E8 deposits are intermittently distributed because of erosion by the E7 deposits. Below the E8 deposits, 


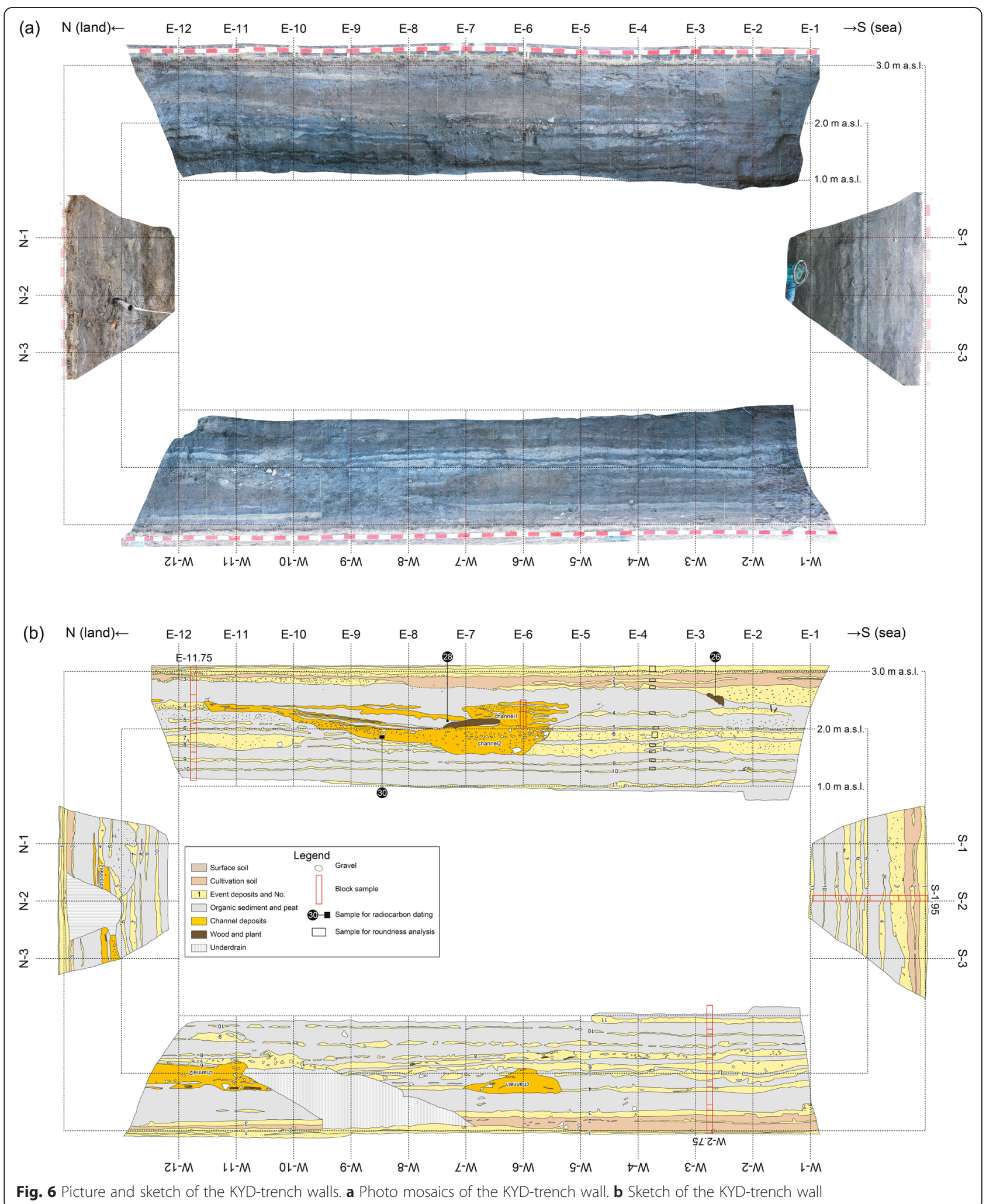

the upper and basal contacts of the event deposits have been disturbed by plant bioturbation. The E9 and E10 deposits are very thin and similarly disturbed by plant bioturbation, but are nonetheless traceable in the KYDtrench (Fig. 6). The E11 deposits are traceable in the southern half of the KYD-trench and distributed under 


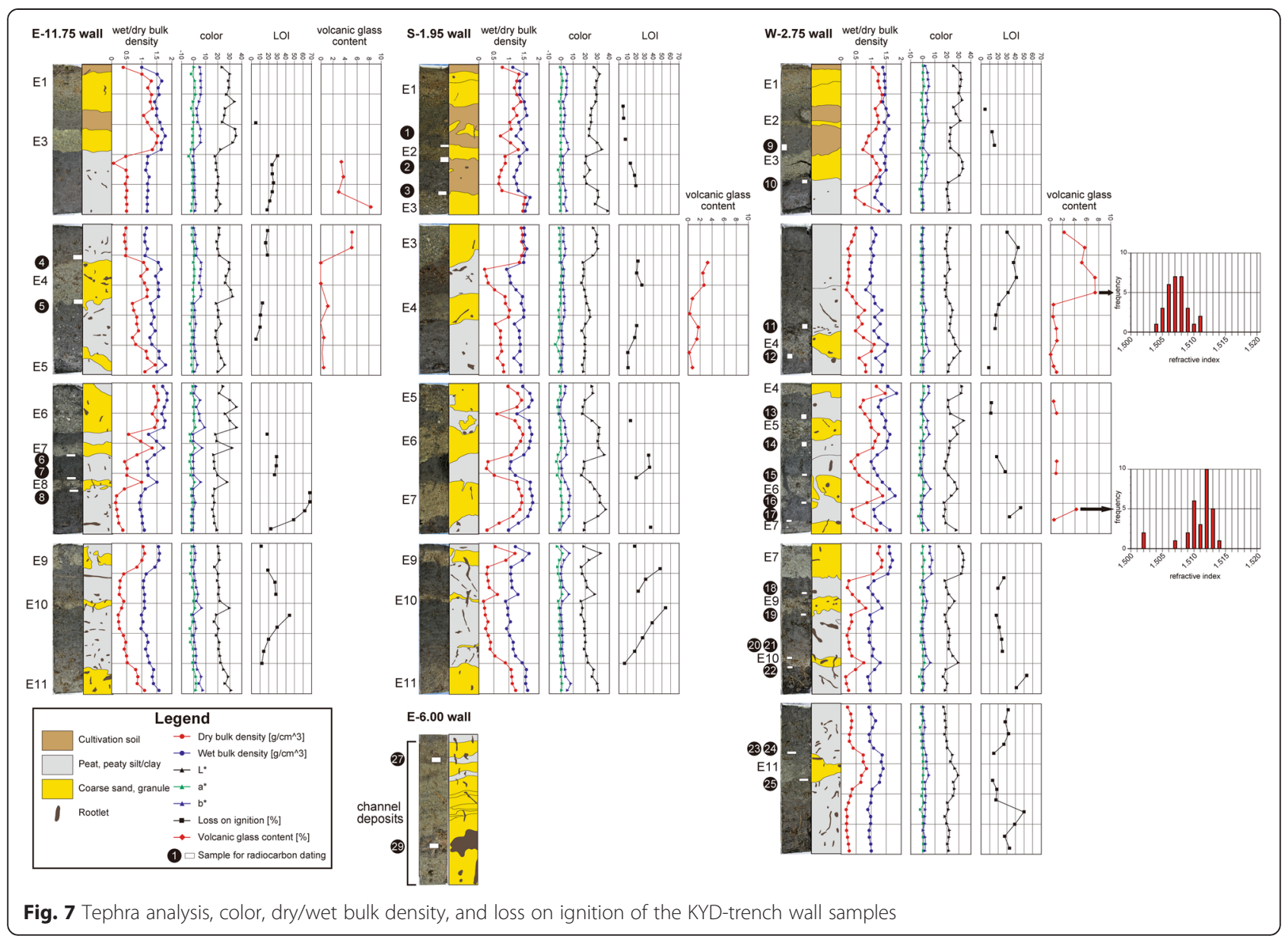

the trench bottom in the northern half (Fig. 6). The E11 deposits are of medium thickness and contain fine grains (coarse to medium sand).

The marsh deposits are composed of plant remains and organic sediments. Their densities are inversely correlated with their LOIs and indirectly indicate their organic carbon content and degree of decomposition (Fig. 7). Color, in particular, the $\mathrm{L}^{*}$ and $\mathrm{b}^{*}$ parameters, is correlated with density, whereas the LOI fluctuates between event deposits. Macroscopically, the LOI decreases from the

Table 3 Characteristics of event deposits in the KYD-trench

\begin{tabular}{|c|c|c|c|c|c|c|c|c|}
\hline $\begin{array}{l}\text { Event } \\
\text { deposits }\end{array}$ & $\begin{array}{l}\text { General } \\
\text { thickness }\end{array}$ & $\begin{array}{l}\text { Comparison of } \\
\text { grain size among } \\
\text { event deposits }\end{array}$ & General grain size & $\begin{array}{l}\text { Measured } \\
\text { thickness } \\
{[\mathrm{cm}]}\end{array}$ & $\begin{array}{l}\text { Upper } \\
\text { contact }\end{array}$ & Basal contact & $\begin{array}{l}\text { Gravel } \\
\text { content } \\
{[w t \%]}\end{array}$ & $\begin{array}{l}\text { Roundness } \\
\text { (well-rounded + } \\
\text { rounded) [\%] }\end{array}$ \\
\hline E1 & Medium & Coarse & $\begin{array}{l}\text { Upper: granule to } \\
\text { medium sand, Lower: } \\
\text { pebble to coarse sand }\end{array}$ & $3-20$ & - & Sharp & $10-28$ & $45-66$ \\
\hline E2 & Thin & Medium & Granule to coarse sand & $1-8$ & Disturbed & Sharp & $8-19$ & $13-53$ \\
\hline E3 & Thick & Coarse & Granule to coarse sand & $2-38$ & Sharp & Sharp & $11-55$ & $48-86$ \\
\hline E4 & Medium & Fine & Granule to fine sand & $3-16$ & Disturbed & Sharp & $2-18$ & $32-41$ \\
\hline E5 & Medium & Medium & Granule to coarse sand & $2-13$ & Disturbed & Sharp & $7-24$ & $30-56$ \\
\hline E6 & Thick & Medium & Granule to coarse sand & $1-24$ & Sharp & Sharp & $18-35$ & $16-62$ \\
\hline E7 & Thick & Medium & Granule to coarse sand & $2-28$ & Disturbed/sharp & Sharp & $2-31$ & $26-67$ \\
\hline E8 & Thin & Fine & Coarse to medium sand & $1-7$ & Disturbed & Disturbed & $8-10$ & $16-45$ \\
\hline E9 & Thin & Fine & Granule to medium sand & $2-18$ & Disturbed & Disturbed/sharp & $8-17$ & $12-42$ \\
\hline E10 & Thin & Fine & Coarse to medium sand & $1-9$ & Disturbed & Disturbed & $3-11$ & $14-43$ \\
\hline E11 & Medium & Fine & Coarse to medium sand & $2-13$ & Disturbed & Disturbed & $3-4$ & $50-61$ \\
\hline
\end{tabular}


trench bottom to the E4 deposits and increases from the E4 deposits to the E3 deposits.

The channel fill deposits exhibit two cross-sectional geometries and compositions, categorized as Channel 1 and Channel 2 (Fig. 6). Channel 1 is distributed from grid $\mathrm{N}-5$ to $\mathrm{N}-10$ and from grid $\mathrm{W}-5.5$ to $\mathrm{W}-7$ (Fig. 6). From the altitude of the channel bottom in both walls, the flow direction of Channel 1 was determined as east to west. Sediments are finer in Channel 1 than in Channel 2, comprising coarse sand to fine pebbles, and interbedded with peaty silt. Channel 2 is distributed from grid $\mathrm{N}-1$ to $\mathrm{W}-10$ and from grid E-5.5 to E-11.5 and flows from northwest to southeast (Fig. 6). The composition is poorly sorted pebble to cobble.

The artificial fill deposits with a buried PVC pipe, distributed from grid $\mathrm{W}-7$ to $\mathrm{W}-11$ and from grid $\mathrm{N}-1.5$ to $\mathrm{N}-2.5$ (Fig. 6), were identified from interviews with landowners as underdrains constructed $40-50$ years ago.

The cultivation soil is distinguished from marsh deposits by its different particle composition, color, and texture. This soil type is interbedded between the E3 and E1 deposits (Fig. 6). Event deposits, marsh deposits, and cultivation soil are also easily distinguishable by their density and color (Fig. 7). The dry bulk density of cultivation soil is intermediate between low-density marsh deposits and high-density event deposits.

According to radiocarbon dating of these marsh and channel deposits (Figs. 6, 7, and 8; Table 4), the sediments in the KYD-trench wall provide a continuous record since approximately $4000 \mathrm{cal}$. BP.

\section{Description of the canal-trench}

Event deposits (the E1, E2, and E3 deposits), other event deposits, cultivation soil/peat, and debris flow deposits were identified in the canal-trench (Figs. 4 and 9). Debris flow deposits are distinguished by poorly sorted gravel beds interfingered with cultivation soil/peat in the geometric cross-section (Fig. 5c). Although the E1 deposits are traceable, the original thickness of the E1 layer has been obscured by artificial modification following the 2011

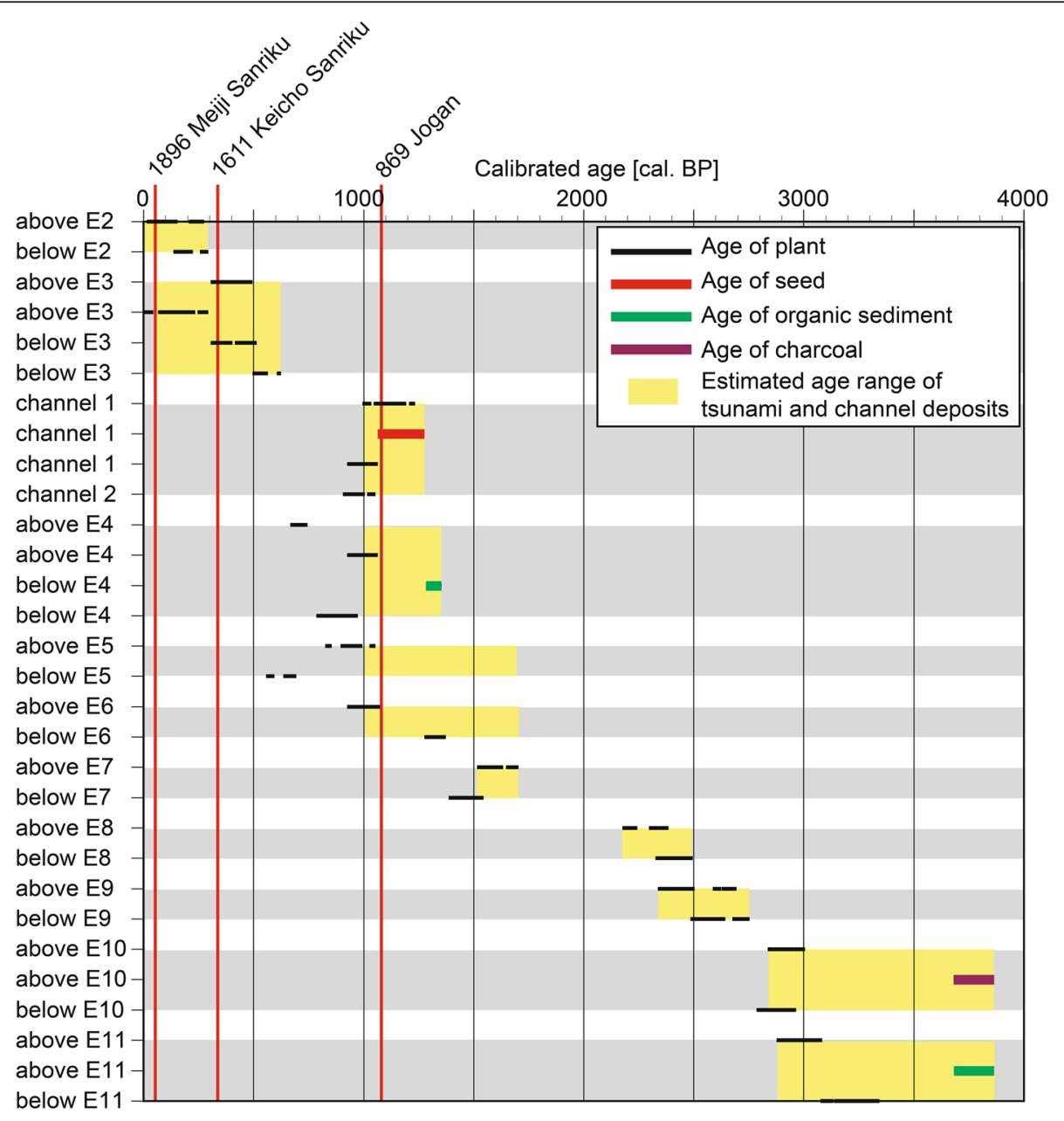

Fig. 8 Event age diagram in the KYD-trench 
Table 4 Radiocarbon ages and calibrated ages

\begin{tabular}{|c|c|c|c|c|c|c|c|c|c|}
\hline Sample no. & $\begin{array}{l}\text { Sample } \\
\text { name }\end{array}$ & Labo no. & $\begin{array}{l}\text { Sample } \\
\text { position }\end{array}$ & Grid no. & Depth [m] & Material & $\begin{array}{l}\delta^{13} \mathrm{C} \\
{[\% 0]}\end{array}$ & $\begin{array}{l}\text { Conventional } \\
{ }^{14} \mathrm{C} \text { age [yrBP] }\end{array}$ & Calibrated age (2б) [calBP] \\
\hline 1 & KYD-TrS-1 & IAAA-131322 & Above E2 & S-1.95 & 0.27 & Plant & -25.3 & $110 \pm 20$ & $\begin{array}{l}270-210(27.4 \%), 150-20 \\
(67.9 \%)\end{array}$ \\
\hline 2 & KYD-TrS-2 & IAAA-131323 & Below E2 & S-1.95 & $0.31-0.33$ & Plant & -26.7 & $190 \pm 20$ & $\begin{array}{l}290-260(19.6 \%), 220-140 \\
(52.9 \%), 20-(22.9 \%)\end{array}$ \\
\hline 3 & KYD-TrS-3 & Beta-357404 & Above E3 & S-1.95 & 0.43 & Plant & -28.8 & $340 \pm 30$ & $490-310(95.4 \%)$ \\
\hline 4 & KYD-TrE-1 & IAAA-131320 & Above E4 & $\mathrm{E}-11.75$ & $0.60-0.62$ & Plant & -28.0 & $790 \pm 20$ & 740-670 (95.4 \%) \\
\hline 5 & KYD-TrE-2 & IAAA-131321 & Below E4 & $\mathrm{E}-11.75$ & $0.74-0.76$ & $\begin{array}{l}\text { Organic } \\
\text { sediment }\end{array}$ & -25.8 & $1420 \pm 20$ & 1350-1290 (95.4 \%) \\
\hline 6 & KYD-TrE-3 & Beta-341796 & Below E7 & $\mathrm{E}-11.75$ & $1.23-1.24$ & Plant & -24.8 & $1570 \pm 30$ & 1540-1390 (95.4 \%) \\
\hline 7 & KYD-TrE-4 & Beta-341572 & Above E8 & $\mathrm{E}-11.75$ & $1.31-1.32$ & Plant & -25.1 & $2320 \pm 30$ & $\begin{array}{l}2380-2300(90.1 \%), 2240-2180 \\
(5.3 \%)\end{array}$ \\
\hline 8 & KYD-TrE-5 & Beta-341797 & Below E8 & $\mathrm{E}-11.75$ & $1.35-1.36$ & Plant & -26.8 & $2360 \pm 30$ & 2490-2330 (95.4\%) \\
\hline 9 & KYD-TrW-1 & IAAA-131324 & Above E3 & $W-2.75$ & $0.27-0.29$ & Plant & -25.5 & $150 \pm 20$ & $\begin{array}{l}290-250(15.7 \%), 230-130 \\
(48.1 \%), 120-70(13.1 \%) \\
40-0(18.5 \%)\end{array}$ \\
\hline 10 & KYD-TrW-2 & Beta-339851 & Below E3 & $W-2.75$ & $0.39-0.41$ & Plant & -27.7 & $370 \pm 30$ & $\begin{array}{l}510-420(55.0 \%), 400-310 \\
(40.4 \%)\end{array}$ \\
\hline 11 & KYD-TrW-3 & Beta-339855 & Above E4 & $W-2.75$ & $0.84-0.86$ & Plant & -29.1 & $1090 \pm 30$ & 1060-930 (95.4 \%) \\
\hline 12 & KYD-TrW-4 & Beta-339856 & Below E4 & $W-2.75$ & $0.94-0.96$ & Plant & -25.7 & $990 \pm 30$ & $\begin{array}{l}970-890(57.4 \%), 880-790 \\
(38.0 \%)\end{array}$ \\
\hline 13 & KYD-TrW-5 & Beta-339857 & Above E5 & $W-2.75$ & $1.10-1.12$ & Plant & -26.8 & $1030 \pm 30$ & $\begin{array}{l}1050-1030(2.8 \%), 990-900 \\
(91.9 \%), 850-830(0.7 \%)\end{array}$ \\
\hline 14 & KYD-TrW-6 & Beta-341794 & Below E5 & $W-2.75$ & $1.19-1.21$ & Plant & -26.3 & $700 \pm 30$ & $\begin{array}{l}690-640(77.5 \%), 590-560 \\
(17.9 \%)\end{array}$ \\
\hline 15 & KYD-TrW-7 & Beta-339858 & Above E6 & $W-2.75$ & $1.30-1.31$ & Plant & -26.1 & $1100 \pm 30$ & 1070-930 (95.4 \%) \\
\hline 16 & KYD-TrW-8 & Beta-341795 & Below E6 & W-2.75 & $1.39-1.40$ & Plant & -26.4 & $1420 \pm 30$ & 1370-1280 (95.4\%) \\
\hline 17 & KYD-TrW-9 & Beta-339859 & Above E7 & $W-2.75$ & $1.45-1.46$ & Plant & -27.6 & $1680 \pm 30$ & $\begin{array}{l}1700-1650(10.2 \%), 1630-1520 \\
(85.2 \%)\end{array}$ \\
\hline 18 & KYD-TrW-10 & Beta-339861 & Above E9 & $W-2.75$ & $1.66-1.67$ & Plant & -26.9 & $2410 \pm 30$ & $\begin{array}{l}2690-2630(11.2 \%), 2620-2590 \\
(2.9 \%), 2500-2340(81.3 \%)\end{array}$ \\
\hline 19 & KYD-TrW-11 & Beta-341798 & Below E9 & $W-2.75$ & $1.73-1.74$ & Plant & -24.5 & $2530 \pm 30$ & $\begin{array}{l}2750-2680(35.8 \%), 2640-2490 \\
(59.6 \%)\end{array}$ \\
\hline 20 & KYD-TrW-12 & Beta-339862 & Above E10 & $W-2.75$ & $1.87-1.88$ & Plant & -27.2 & $2810 \pm 30$ & $3000-2840(95.4 \%)$ \\
\hline 21 & KYD-TrW-13 & Beta-340343 & Above E10 & $W-2.75$ & $1.87-1.88$ & Charcoal & -25.4 & $3500 \pm 30$ & $3860-3690$ (95.4 \%) \\
\hline 22 & KYD-TrW-14 & Beta-341799 & Below E10 & W-2.75 & $1.92-1.93$ & Plant & -28.0 & $2780 \pm 30$ & 2960-2790 (95.4 \%) \\
\hline 23 & KYD-TrW-15 & Beta-339863 & Above E11 & W-2.75 & $2.16-2.17$ & Plant & -26.1 & $2870 \pm 30$ & 3080-2880 (95.4 \%) \\
\hline 24 & KYD-TrW-16 & IAAA-131669 & Above E11 & $W-2.75$ & $2.16-2.17$ & $\begin{array}{l}\text { Organic } \\
\text { sediment }\end{array}$ & -23.5 & $3500 \pm 30$ & $3860-3690$ (95.4 \%) \\
\hline 25 & KYD-TrW-17 & Beta-341800 & Below E11 & $W-2.75$ & $2.25-2.26$ & Plant & -25.8 & $3020 \pm 30$ & $\begin{array}{l}3340-3140(92.0 \%), 3130-3110 \\
(1.4 \%), 3100-3080(2.0 \%)\end{array}$ \\
\hline 26 & KYD-Tr-a & Beta-357405 & Below E3 & $E-2.40-2.60$ & $0.50-0.70$ & Plant & -28.2 & $500 \pm 30$ & 620-610 (0.7 \%), 560-500 (94.7\%) \\
\hline 27 & KYD-Tr-b & Beta-339852 & Channel 1 & $E-6.00$ & $0.68-0.70$ & Plant & -27.0 & $1190 \pm 30$ & $\begin{array}{l}1230-1210(2.9 \%), 1190-1050 \\
(89.0 \%), 1030-1000(3.5 \%)\end{array}$ \\
\hline 28 & KYD-Tr-C & Beta-339853 & Channel 1 & E-7.30 & 0.95 & $\begin{array}{l}\text { Seed } \\
\text { (Juglans sp.) }\end{array}$ & -25.3 & $1240 \pm 30$ & 1270-1070 (95.4\%) \\
\hline 29 & KYD-Tr-d & Beta-357406 & Channel 1 & $E-6.00$ & $0.94-0.99$ & Plant & -28.9 & $1090 \pm 30$ & 1060-930 (95.4\%) \\
\hline 30 & KYD-Tr-e & Beta-339854 & Channel 2 & E-8.45 & 1.30 & Plant & -25.1 & $1040 \pm 30$ & $\begin{array}{l}1050-1020(5.2 \%), 1000-910 \\
(90.2 \%)\end{array}$ \\
\hline
\end{tabular}




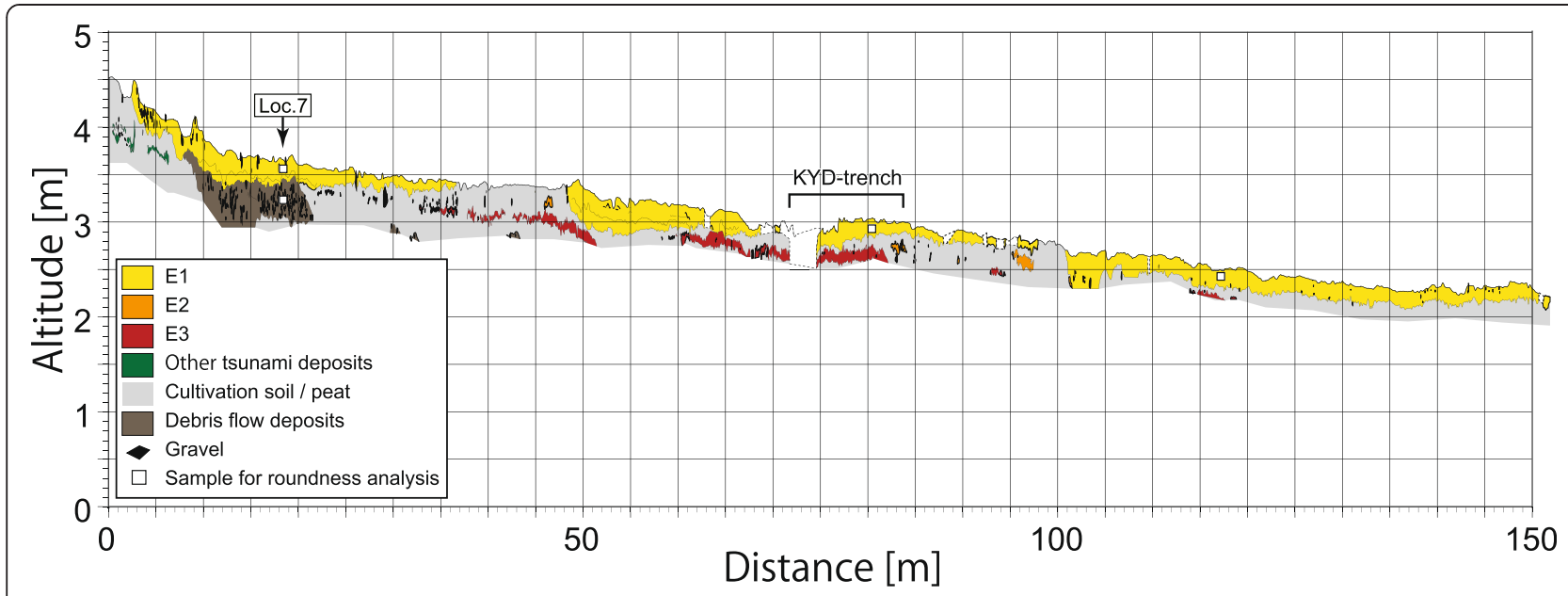

Fig. 9 Sketch of the canal-trench

event. The E2 deposits are intermittently distributed and some of them have been modified by cultivation. The E3 deposits are traceable and partially disturbed. The E3 layer is less than $20 \mathrm{~cm}$ thick, decreasing in the landward direction.

\section{Particle roundness}

Event deposits were sampled from the KYD- and canaltrenches (Figs. 6 and 9). Modern beach and river deposits, and debris flow deposits, were sampled from the canaltrench and outcrops (Figs. 4 and 9). Next, the origins of the event deposits were inferred from their roundness measures. Modern river and debris flow deposits consist almost entirely of angular/very angular and sub-rounded/ sub-angular gravels, with no well-rounded/rounded gravels (Fig. 10a-c). Conversely, modern beach deposits contain well-rounded/rounded and sub-rounded/sub-angular gravels; angular/very angular gravels are absent (Fig. 10d). The E1 and E3 deposits (Fig. 10e, f) are similar to modern beach deposits, with high contents of well-rounded/ rounded and sub-rounded/sub-angular gravels. The clear roundness differences between modern river and beach deposits are shown in the triangular diagram of Fig. 10g. The roundness composition of all event deposits in the KYD-trench is shown in Fig. 10h. In all samples, the proportion of well-rounded/rounded gravel contents exceeds $10 \%$, while the angular/very angular gravel content is below $40 \%$. Unlike the terrestrial deposits, all event deposits contain beach gravels.

\section{Tephra analysis}

From the radiocarbon dating, we determined that the invisible To-a (AD915 (1035 cal. BP)) lies between the E3 and E5 deposits. The volcanic glass contents in each trench wall sample increase after the E4 deposition (Fig. 7).
In particular, in the east and west walls, the volcanic glass content suddenly increases and gradually decreases from the lower to upper parts, indicating an invisible tephra horizon. However, this trend is absent in the south wall, probably because it has been eroded by the E3 deposits.

The origins of the volcanic glass shards were determined from their refractive indices. Above the E4 deposits, the region of highest volcanic glass content, the glass refractive index ranges from 1.504 to 1.511 (mode: 1.507-1.508). Below the E4 deposits, the refractive index ranges from 1.509 to 1.514 (mode: 1.512). Furthermore, we analyzed the major element compositions of the volcanic glass shards above the E4 deposits (Table 5).

\section{Discussion}

\section{Identification of tsunami deposits}

The roundness similarities between the event and beach deposits (Fig. 10) indicate that event deposits were transported from beach and beach ridges to the inland trench sites. Landward transport from the sea is expected in tsunami and storm events. The general characteristics of tsunami and storm deposits have been reported by many researchers (Morton et al. 2007; Kortekaas and Dawson 2007; Switzer and Jones 2008; Goff et al. 2012; Phantuwongraj and Choowong 2012). On average, tsunami deposits are generally thinner than storm deposits (Morton et al. 2007; Phantuwongraj and Choowong 2012), and sedimentary structure is less common in tsunami deposits than in storm deposits (Morton et al. 2007; Kortekaas and Dawson 2007; Switzer and Jones 2008; Goff et al. 2012). The basal contact of both sediments is unconformable or erosional (Morton et al. 2007; Kortekaas and Dawson 2007; Switzer and Jones 2008; Goff et al. 2012; Phantuwongraj and Choowong 2012), although tsunami deposits sometimes show a loading structure (Goff et al. 

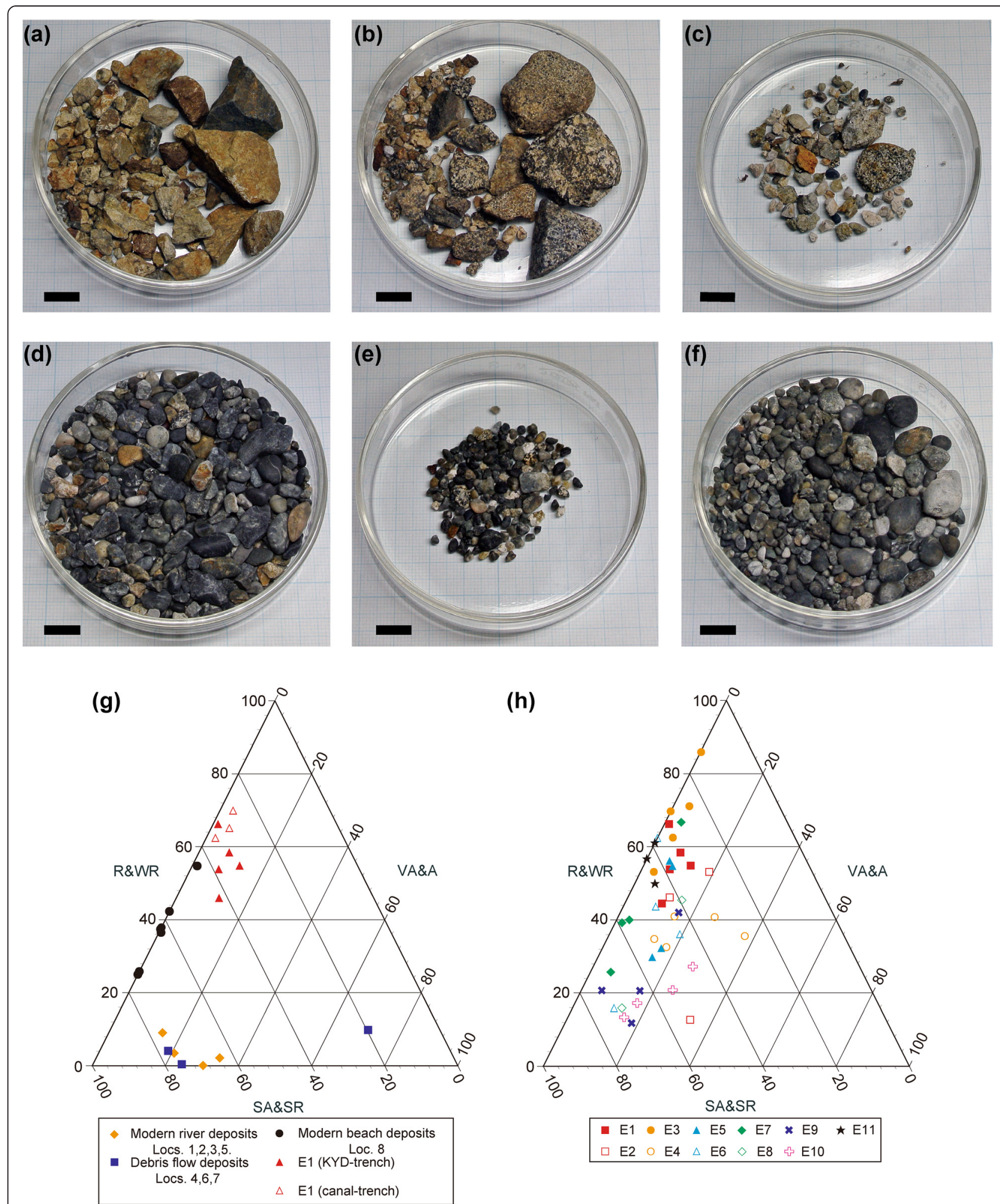

Fig. 10 Photographs and roundness of tsunami deposits, channel deposits, debris flow deposits, modern beach deposits, and modern river deposits. a Modern river deposits (Loc. 1). b Modern river deposits (Loc. 2). c Debris flow deposits in the canal-trench (Loc. 7). d Modern beach deposits (Loc. 8). e The E1 deposits in the south wall of the KYD-trench. $\mathbf{f}$ The E3 deposits in the south wall of the KYD-trench. $\mathbf{g}$ Comparison of the 2011 Tohoku-oki tsunami deposits, beach deposits, modern river deposits, and debris flow deposits; $\mathbf{h}$ tsunami deposits in the KYD-trench wall. Scale in the photographs is $1 \mathrm{~cm}$. In the triangular diagrams, $x$-axis indicates well-rounded/rounded, $y$-axis indicates sub-rounded/sub-angular, and z-axis indicates very angular/angular 
Table 5 Major element compositions of volcanic glass shards

\begin{tabular}{|c|c|c|c|c|c|c|c|c|c|c|c|}
\hline & $\mathrm{SiO}_{2}$ & $\mathrm{TiO}_{2}$ & $\mathrm{Al}_{2} \mathrm{O}_{3}$ & $\mathrm{FeO}$ & $\mathrm{MnO}$ & $\mathrm{MgO}$ & $\mathrm{CaO}$ & $\mathrm{Na}_{2} \mathrm{O}$ & $\mathrm{K}_{2} \mathrm{O}$ & $n$ & Total $^{a}$ \\
\hline ONM-GS1-0.42 & 77.0 & 0.4 & 12.7 & 1.8 & 0.1 & 0.4 & 2.1 & 4.1 & 1.4 & 15 & 97.5 \\
\hline Ishimura et al. (2014) & 0.1 & 0.1 & 0.1 & 0.1 & 0.1 & 0.1 & 0.1 & 0.1 & 0.0 & & 0.6 \\
\hline NTR-Br-34.93 & 77.0 & 0.4 & 12.8 & 1.8 & 0.1 & 0.4 & 2.1 & 4.1 & 1.4 & 15 & 96.1 \\
\hline Ishimura et al. (2014) & 0.3 & 0.1 & 0.2 & 0.1 & 0.1 & 0.0 & 0.1 & 0.3 & 0.1 & & 0.7 \\
\hline To-a (35) & 77.50 & 0.36 & 12.73 & 1.62 & 0.09 & 0.38 & 1.81 & 3.90 & 1.37 & 19 & 98.41 \\
\hline Aoki and Machida (2006) & 0.7 & 0.0 & 0.4 & 0.2 & 0.0 & 0.1 & 0.2 & 0.1 & 0.1 & & 1.4 \\
\hline To-a (36) & 77.69 & 0.36 & 12.74 & 1.66 & 0.09 & 0.35 & 1.80 & 3.99 & 1.31 & 8 & 98.53 \\
\hline Aoki and Machida (2006) & 0.6 & 0.1 & 0.3 & 0.1 & 0.0 & 0.0 & 0.1 & 0.2 & 0.0 & & 1.3 \\
\hline To-a (37) & 76.17 & 0.42 & 13.41 & 1.89 & 0.09 & 0.38 & 1.99 & 4.08 & 1.56 & 18 & 92.89 \\
\hline Aoki and Machida (2006) & 0.3 & 0.0 & 0.2 & 0.1 & 0.0 & 0.0 & 0.1 & 0.1 & 0.1 & & 1.1 \\
\hline KYD-TrW sec. $220-25$ cm & 77.1 & 0.4 & 12.7 & 1.8 & 0.1 & 0.4 & 2.1 & 4.1 & 1.4 & 15 & 94.4 \\
\hline (This study) & 0.3 & 0.1 & 0.2 & 0.2 & 0.1 & 0.0 & 0.0 & 0.1 & 0.1 & & 1.3 \\
\hline
\end{tabular}

Number on upper line shows a mean value and that on lower line shows a standard deviation. Measured values are recalculated to $100 \%$ on a water-free basis. Results of Aoki and Machida (2006) are shown for comparison and numbers in brackets show sample number in the reference

${ }^{a}$ Raw data before recalculations

2012). On transect scales (several hundred meters), the cross-shore geometries of tsunami and storm deposits are characterized by "broad thin drapes with tabular or landward thinning" and "narrow thick deposits with abrupt landward thinning," respectively (Morton et al. 2007). These characteristics of tsunami deposits are recognized in the event deposits in the trenches. In the KYDtrench (length $=12 \mathrm{~m}$ ), all event deposits are generally thinner than $20 \mathrm{~cm}$ and appear as draped or eroded paleosurfaces. Some of them exhibit a loading structure. In the canal-trench (length $=150 \mathrm{~m}$ ), the E1 and E3 deposits appear as draped deposits, with landward thinning in the E3 deposits. Furthermore, the KYD-trench is located $300 \mathrm{~m}$ inland from the beach, and landowners reported no storm deposits in the trench sites during the past 40-50 years. In contrast, the paleo-shoreline after the $\mathrm{To}-\mathrm{Cu}$ deposition (about $6 \mathrm{ka}$ ) is estimated to be at least on the seaside of the KYD-Br1 site (Fig. 4). The elevations of primary To- $\mathrm{Cu}$ tephra within the KYD-Br1 to KYD-Br3 cores are $-1.60,-1.82$, and $-3.08 \mathrm{~m}$ a.s.l., respectively, showing landward deepening, and sediments deposited after the $\mathrm{To}-\mathrm{Cu}$ deposition are consistent with non-marine environments such as marsh (Ishimura et al. 2014). From these data, we consider that the present depositional setting (beach ridge and behind marsh) around the trench sites was already established by $6 \mathrm{ka}$. Therefore, prior to the $\mathrm{To}-\mathrm{Cu}$ fall, the paleo-surface topography places the paleo-shoreline on the seaside of the KYDBr1 core site. The features of the event deposits and the geomorphological settings from 6 ka to the present, together with the responses of interviewed landowners regarding recent events, indicate that all event deposits in the KYD-trench are sourced from tsunamis rather than storms.

\section{Ages of tsunami deposits and correlation to historical} tsunami event

Radiocarbon dating (Fig. 8, Table 4) suggests that the deposits in the KYD-trench are relatively close in age with no large age gap. Radiocarbon dating of event deposits is performed on plant fragments (such as reeds), because these constitute the youngest material in a sampled horizon. Plant materials in the trench are likely to be fragments of in situ plants, but downward invasion of roots and underground stems should not be ruled out. Thus, the ages of the plant material were assumed to represent the youngest ages of the sampled horizons. In contrast, a charcoal and a hard-shell plant seed (Juglans sp.) (Samples No. 21 and 28; Table 4) are assumed to be transported materials, whose ages mark the older age limit of the sampled horizons. Organic sediments (Samples No. 5 and 24; Table 4) are older than plant fragments, consistent with our radiocarbon dating interpretations. The true age of the sediment is expected to lie between the ages of the plant and other materials. Ishimura et al. (2014) identified To-Cu (6 ka) tephra and Oguni Pumice (7.3 to $7.4 \mathrm{ka}$ ) in the KYD-Br3 core drilled next to the KYD-trench at depths of 4.41$5.98 \mathrm{~m}$ (total thickness of primary and secondary tephra) and $8.55-8.60 \mathrm{~m}$, respectively. The horizons and ages of these sediments are consistent with the radiocarbondated geochronology of the KYD-trench determined in this study.

We estimated the event ages based on radiocarbon dating and the above criteria (Fig. 8, Table 6). The tsunami deposit events are labeled E1-E11 in order of increasing age, considering the age constraint of the next older event. Since the ages of the E5 and E6 deposits were not determined by radiocarbon dating, we interpolated their ages using the radiocarbon ages of the E4 and E7 deposits. 
Table 6 Estimated ages of tsunami deposits and their correlation with historical tsunami events

\begin{tabular}{llll}
\hline & Age [BP] & Most probable historical event & Tephra \\
\hline E1 & & $\begin{array}{l}\text { 2011 Tohoku-oki Earthquake } \\
\text { Tsunami }\end{array}$ & \\
E2 & Modern-290 & 1896 Meiji Sanriku Tsunami & \\
E3 & $0-620$ & 1611 Keicho Sanriku Tsunami & \\
E3/E4 & & \\
E4 & $1000-1350$ & 869 Jogan Tsunami?(no historical & \\
E5 & $1000-1700$ & \\
E6 & $1000-1700$ & \\
E7 & $1520-1700$ & \\
E8 & $2180-2490$ & \\
E9 & $2340-2750$ & \\
E10 & $2840-3860$ & \\
E11 & $2880-3860$ & \\
\hline
\end{tabular}

From these chronological estimations, we can correlate the E2, E3, and E4 deposits to historical tsunamis because these deposits are younger than AD 600.

The ages of the E2 deposits range from modern times to 290 cal. BP (i.e., they are younger than AD 1660). Certainly, the E2 deposits can be correlated to one event among the 1611, 1677, 1793, 1856, 1896, and 1933 events (Table 2). The runup heights (Table 2) and stratigraphic position of the E2 deposits suggest a correlation with the 1933 Showa Sanriku tsunami and the 1896 Meiji Sanriku tsunami, because the height of the beach ridge at Koyadori was approximately $5 \mathrm{~m}$ a.s.l. in both events. Although both tsunamis inundated up to the trench sites, only single-event deposits were identified from AD 2011 to 1660. Tsunami deposits can be absent for several reasons stated as follows: 1) disturbance and/or removal by cultivation, 2) erosion by succeeding tsunami events, 3) sediment availability, and 4) tsunami size. The first cause is easily explained. If sediments were deposited by the 1896 Meiji Sanriku and the 1933 Showa Sanriku tsunamis, the latter deposits would first be disturbed and removed by cultivation processes. In this case, we would correlate the preserved tsunami deposits to the 1896 Meiji Sanriku tsunami. Regarding the second cause, the 1896 deposits might have been eroded by the 1933 deposits. However, the E2 deposits show no clear base erosion in either the KYD- or canal-trenches, and no remnants of eroded tsunami deposits are evident between the E2 and E3 deposits. Thus, the second cause is inconsistent with the observations. Meanwhile, the third cause is inconsistent with the study site setting. If a large tsunami, with height exceeding that of the beach ridge, hits Koyadori, sediments of beach and beach ridge must be transported landward because there is much sediment in the coast and the beach was re-established a few months after the 2011 event. The forth cause, tsunami size, relates to the transportation and preservation of tsunami deposits. The inundation heights were larger in the 1896 event than in the 1933 event (Table 2). Thus, we can easily expect that the volume of the 1896 tsunami deposits exceeded that of the 1933 deposits. This also suggests that the 1896 tsunami deposits were better preserved than the 1933 tsunami deposits. From these considerations, we inferred that the E2 deposits are correlated to the 1896 Meiji Sanriku tsunami.

Considering the above correlation of the E2 deposits, the age of the E3 deposits was estimated as 54-620 cal. BP (AD 1896-1330). Thus, the E3 deposits can be correlated to one event among the 1454, 1611, 1677, 1793, and 1856 events (Table 2). Based on the tsunami runup height of these events (Table 2), the E3 deposits are most probably associated with the 1611 Keicho Sanriku tsunami. The E3 deposits are thick and composed of coarse materials (Table 3), and are traceable in the canal-trench (Fig. 9). Assuming a similar depositional setting from about 6 ka onward, we considered that the feature differences (thickness and grain size) among event deposits roughly indicate the tsunami size. The features of the E3 deposits (Table 3) suggest a large, very energetic tsunami. According to a local legend (Imamura 1934), the 1611 Keicho Sanriku tsunami inundated and surged through the Koyadori-Oura pass (Fig. 2). This indicates that the 1611 Keicho Sanriku tsunami was at least as high as the 2011 Tohoku-oki tsunami, since the latter failed to reach the geomorphic pass.

According to the radiocarbon dates of the channel deposits, the E4 deposits are aged 1000-1350 cal. BP (AD 950-600), and possibly correlate with the 869 Jogan tsunami. By targeting our tephra analysis at the To-a (AD 915) horizon, we determined an absolute timing for the E4 deposits. The increased content of volcanic glass above the E4 deposits (Fig. 7) suggests a tephra fall after the E4 sedimentation. The refractive index of volcanic glass shards above the E4 deposits ranged from 1.504 to 1.511 (mode: 1.507-1.508), which includes the To-a tephra range (Machida and Arai 2003; Ishimura et al. 2014). Similarly, the chemical compositions of volcanic glass shards were consistent with previously reported To-a compositions (Aoki and Machida 2006; Ishimura et al. 2014). From these data, we inferred that the To-a tephra fell between the E4 and E3 deposits, and we assigned the E4 deposits to the 869 Jogan tsunami. This identification based on radiocarbon dating and tephra provides significant information on the size and source of the 869 Jogan tsunami and earthquake, indicating that this tsunami reached the middle part of the Sanriku Coast and its inundation area was possibly as large as the 2011 event. Since the Jogan tsunami is not reported in historical records around 
Koyadori and insufficient information is available for regionally and chronologically identifying the tsunami deposits along the Sanriku Coast, this finding requires confirmation in paleographical and geological researches.

\section{Tsunami ages and their intervals}

Conclusive age estimates and correlations of historical tsunami events are summarized in Table 6. Although some ambiguity of the ages remains, we calculated the average interval of tsunami occurrence as 290-390 years. Before considering the approximate age intervals of tsunami events, we need to discuss the preservation potential of tsunami deposits at this site. Szczucinski (2012) and Spiske et al. (2013) mentioned the preservation potential of tsunami deposits in tropical and temperate climate regions, respectively, and showed that the characteristics of tsunami deposits (thickness and sedimentary structure) degrade over time. Spiske et al. (2013) emphasized the significance of the preservation potential in assessing the intervals and frequencies of tsunamis, because tsunami deposits are not necessarily preserved in whole inundated areas. They identified five determining factors of preservation potential as follows: 1) composition and genetic type of the tsunami deposits, 2) coastal topography and depositional environment, 3) co- and post-seismic uplift or subsidence, 4) climate, and 5) anthropogenic modification. In Koyadori, tsunami deposits originated from beach and beach ridge deposits and are coarser than those reported in Szczucinski (2012) and Spiske et al. (2013), indicating larger resistance to post-tsunami surface processes. As mentioned above, the sedimentary environment has remained largely unchanged since $6 \mathrm{ka}$, and the beach ridge and behind-marsh environment have maintained accommodation space for tsunami and marsh deposits. The 2011 event was followed by co- and postseismic subsidence (Ozawa et al. 2011), enhancing the preservation environment of tsunami deposits. The Sanriku Coast has a temperate climate and experiences fewer and weaker storms and high tide events (such as typhoons) than the western part of Japan. According to interviews with landowners, no storm deposits have settled in the trench sites during the past $40-50$ years. Artificial modification is limited to deposits younger than E3 at this site. Moreover, 2011 tsunami deposits were found in pits and coring surveys conducted around the KYD-trench in 2013 and 2014. These deposits were clearly identifiable, despite being partially bioturbated by grass and reed. Such vegetation covered the tsunami deposits, preventing erosion and removal by post-tsunami surface processes. Even in the event of dense bioturbation, tsunami deposits are easily identified by their grain composition, size, and roundness, which widely differ from those of background deposits (e.g., peat and debris flow deposits). Therefore, we conclude that the preservation potential of tsunami deposits is very high in Koyadori. Consequently, the calculated average interval probably truly reflects the interval and frequency of large tsunamis.

The calculated average interval (290-390 years) is shorter than that obtained for the Sendai and Ishinomaki Plains (Sawai et al. 2007; 2012; Shishikura et al. 2007), reflecting the high frequency of large tsunamis causing destructive damage along the Sanriku Coast. However, if we have correctly correlated the historical deposits to the historical tsunami events, we can state the age intervals from the E1 to E4 deposits as 115, 285, and 742 years, respectively. This variability probably indicates the diversity of the tsunami generation mechanism (e.g., large earthquake, tsunami earthquake, submarine mass failure, and tsunami of distant origin) and/or the combination of several types of large earthquakes from different sources around the Japan Trench.

On the other hand, the size of historical and paleotsunamis can be estimated from our results because the 1896 Meiji Sanriku tsunami inundated the KYD-trench site and transported tsunami deposits there. In contrast, neither the 1968 Tokachi-oki tsunami (nearby source, runup height approximately $3 \mathrm{~m}$ around Koyadori; Table 2 ) nor the 1960 Chile tsunami (distant source, runup height approximately $4 \mathrm{~m}$ around Koyadori; Table 2) inundated, perhaps because they were blocked by beach ridges (height approximately $5 \mathrm{~m}$ a.s.l.). Furthermore, the environmental setting at the study site has been established since approximately $6 \mathrm{ka}$. These observations preliminarily suggest that tsunamis larger than the 1896 Meiji Sanriku tsunami occur at the calculated average interval, providing a first step for assessing the risk and size of tsunamis along the Sanriku Coast. To understand the tsunami generation mechanism and earthquakes along the Japan Trench, we require detailed information of ages, intervals, and sizes of historical and paleo-tsunamis at multiple sites.

\section{Conclusions}

We identified eleven tsunami deposits, including the 2011 tsunami deposits, based on sedimentary structure and continuity in two trenches and comparisons of the roundness of the gravel composing the event deposits. Radiocarbon dating and tephra analysis allowed us to establish the geochronology in the KYD-trench wall sediments and to correlate tsunami deposits with historical tsunami events. The four younger tsunami deposits (the E1-E4 deposits) are correlated with the 2011 Tohoku-oki tsunami, the 1896 Meiji Sanriku tsunami, the 1611 Keicho Sanriku tsunami, and the 869 Jogan tsunami events, respectively. The average interval of tsunami occurrence at Koyadori is estimated at 290-390 years based on continuous records in the KYD-trench. However, the age intervals between the E1 to E4 deposits are variable (E1/E2: 115 years, E2/E3: 285 years, E3/E4: 742 years), likely 
reflecting the diversity of the tsunami generation mechanism and/or different earthquake sources around the Japan Trench. By correlating the historical tsunami runup height data with extant tsunami deposits, we could preliminarily estimate the sizes of paleo-tsunamis at the study site. In the future study, we need to confirm our tsunami correlations by correcting many geological data along the Sanriku Coast. Ultimately, we aim to assess tsunami risk and understand the earthquake phenomena around the Japan Trench.

\section{Competing interests}

The authors declare that they have no competing interests.

\section{Authors' contributions}

DI conducted preliminary surveys, chose the study site, collected samples, performed experiments, and wrote the paper. TM designed and directed the project and gave helpful comments for the paper. Both authors read and approved the final manuscript.

\section{Acknowledgements}

We are grateful to Kazuomi Hirakawa, Toshifumi Imaizumi, Shuji Yoshida, Heitaro Kaneda, Tomoo Echigo, and Shinsuke Okada for their comments and helps in the fieldwork. We thank Hiroyuki Tustsumi for permission of using a soil color meter. The landowners of the KYD-trench site are also thanked for allowing us to conduct our surveys on their properties. The editor Ken Ikehara and two anonymous reviewers provided constructive comments that improved the manuscript. This study was a part of "Geophysical and geological studies of earthquakes and tsunamis for off-Tohoku district, Japan" and supported by the Ministry of Education, Culture, Sports, Science, and Technology, Japan (MEXT). This work was supported by Intramural Research Grant for Special Project Researches from International Research Institute of Disaster Science, Tohoku University.

\section{Author details}

${ }^{1}$ Disaster Science Division, International Research Institute of Disaster Science, Tohoku University, 468-1 Aza-aoba, Aramaki, Aoba-ku, Sendai, Miyagi 980-0845, Japan. ²Department of Earth Sciences, Graduate School of Science, Chiba University, 1-33 Yayoi-cho, Inage-ku, Chiba, Chiba 263-8522, Japan.

Received: 11 November 2014 Accepted: 21 May 2015

Published online: 27 June 2015

\section{References}

Aoki K, Machida H (2006) Major element composition of volcanic glass shards in the late Quaternary widespread tephras in Japan-Distribution of tephras using K2O-TiO2 diagrams. Bull Geol Surv Japan 57:239-258

Bos AJ, Busschers FS, Hoek WZ (2012) Organic-facies determination: a key for understanding facies distribution in the basal peat layer of the Holocene Rhine-Meuse delta, The Netherlands. Sedimentology 59:679-703

Danhara T, Yamashita T, Iwano H, Kasuya M (1992) An improved system for measuring refractive index using the thermal immersion method. Quat Int 13(14):89-91

Earthquake Research Committee Headquarters for Earthquake Research Promotion Prime Minister's Office, Government of Japan (1999) Seismic Activity in Japan -Regional perspectives on the characteristics of destructive earthquakes-. Association for the Development of Earthquake. Prediction, Tokyo

Earthquake Research Institute, the University of Tokyo (1934) Reports on the 3 March, Showa 8 Sanriku tsunami. Bull Earthq Res Inst Tokyo Univ, Suppl 1:1-250

Goff J, Chagué-Goff C, Nichol S, Jaffe B, Dominey-Howes D (2012) Progress in palaeotsunami research. Sedi Geol 243-244:70-88

Goldfinger C, Ikeda Y, Yeats RS, Ren J (2013) Superquakes and supercycles. Seis Res Lett 84:1-9

Hamilton S, Shennan I (2005) Late Holocene relative sea-level changes and the earthquake deformation cycle around upper Cook Inlet, Alaska. Quat Sci Rev 24:1479-1498
Haraguchi T, Goya K (2007) Tsunami deposits from Goishi-hama, of Ofunato City, Iwate Prefecture. In: Proceedings of Rekishi-Zishin Meeting 23. Ofunato Plaza Hotel, Ofunato, 15-17 September 2007

Haraguchi T, Ishibe T (2009) Large earthquake model in the central part of Off-Sanriku estimated from tsunami deposits and uplifted event layers. Chikyu Monthly 31:223-230

Haraguchi T, Iwamatsu A (2011) Detailed maps of the impacts of the 2011 Japan tsunami: Vol. 1: Aomori, Iwate and Miyagi prefectures. Kokon-Shoin Publishers Ltd, Tokyo

Haraguchi T, Fujiwara O, Shimazaki K, Imaizumi T (2006a) Tsunami deposits from Ohtsuchi Bay of Sanriku Coast, North Eastern Japan. In: Abstract of Japan Geoscience Union Meeting 2006. Makuhari Messe, Chiba, 14-18 May 2006

Haraguchi T, Torii K, Fujiwara O, Shimazaki K, Imaizumi T (2006b) Subaqueous tsunami deposits from Otsuchi Bay of Sanriku Coast, Northeastern Japan. Chikyu Monthly 28:539-545

Haraguchi T, Torii T, Imaizumi T, Miyauchi T, Shimazaki K (2007) Tsunami deposits from Sanriku coast NE Japan in late Holocene. In: Abstract of Japan Geoscience Union Meeting 2007. Makuhari Messe, Chiba, 19-24 May 2007

Hatori T (1975) Tsunami magnitude and wave source regions of historical Sanriku tsunamis in northeast Japan. Bull Earthq Res Inst 50:397-414

Hatori T (2000) Reexamination of magnitude of historical tsunamis off the Sanriku. Tsunami Eng Tech Rep Tohoku Univ 17:38-48

Hatori T (2009) Regional deviation of inundation heights due to the large Sanriku tsunamis. Histo Earthq 24:41-48

Hayward BW, Grenfell HG, Sabaa AT, Carter R, Cochran U, Lipps JH, Shane PR, Morley MS (2005) Micropaleontological evidence of large earthquakes in the past 7200 years in southern Hawke's Bay, New Zealand. Quat Sci Rev 25:1186-1207

Ikeda Y, Okada S, Tajikara M (2012) Long-term strain buildup in the Northeast Japan arc-trench system and its implications for gigantic strain-release events. J Geol Soc Japan 118:294-312

Imaizumi T, Miyauchi T, Haraguchi T, Shimazaki K, Kagohara K, Sasaki A, Kamal PABM, Goya K (2007) Tsunami deposits along the Sanriku coast and historical earthquakes. In: Proceedings of the 2007 General Meeting of the Association of Japanese Geographers. Toyo University, Tokyo, 20-22 March 2007

Imamura A (1934) Past tsunamis of the Sanriku District. Bull Earthq Res Inst Tokyo Univ, Suppl 1:1-16

Ishimura D, Yamada K, Miyauchi T, Hayase R (2014) Characteristics of tephras interbedded with the Holocene sediments in the Sanriku Coast, northeast Japan. J Geogra 123:671-697

Kawamura K, Sasaki T, Kanamatsu T, Sakaguchi A (2012) Large submarine landslides in the Japan Trench: a new scenario for additional tsunam generation. Geophys Res Lett 39, L05308

Kawamura K, Laberg JS, Kanamatsu T (2014) Potential tsunamigenic submarine landslides in active margins. Marine Geol 356:44-49

Kortekaas S, Dawson AG (2007) Distinguishing tsunami and storm deposits: an example from Martinhal, SW Portugal. Sedi Geol 200:208-221

Machida H, Arai F (2013) Atlas of Tephra in and around Japan [revised edition]. University of Tokyo Press, Tokyo

Minoura K, Nakaya S (1991) Traces of tsunami preserved in inter-tidal lacustrine and marsh deposits: some examples from northeast Japan. J Geol 99:265-287

Minoura K, Imamura F, Sugawara D, Kono Y, Iwashita T (2001) The 869 Jogan tsunami deposit and recurrence interval of large-scale tsunami on the Pacific coast of northeast Japan. J Nat Dis Sci 23:83-88

Morton RA, Gelfenbaum G, Jaffe BE (2007) Physical criteria for distinguishing sandy tsunami and storm deposits using modern examples. Sed Geol 200:184-207

Namegaya Y, Satake K (2014) Reexamination of the A.D. 869 Jogan earthquake size from tsunami deposit distribution, simulated flow depth, and velocity. Geophys Res Lett 41:2297-2303

Namegaya Y, Yata T (2014) Tsunamis which affected the Pacific coast of eastern Japan in medieval times inferred from historical documents. J Seis Soc Japan 2nd ser. 66:73-81

Ozawa S, Nishimura T, Suito H, Kobayashi T, Tobita M, Imakiire T (2011) Coseismic and postseismic slip of the 2011 magnitude-9 Tohoku-Oki earthquake. Nature 475:373-376

Phantuwongraj S, Choowong M (2012) Tsunamis versus storm deposits from Thailand. Nat Hazards 63:31-50

Prefecture I (1969) Record of recovery process from the 1960 Chile earthquake tsunami. Iwate Prefecture, Morioka

Rajendran K (2013) On the recurrence of great subduction zone earthquakes. Curr Sci 104:880-892 
Ramsey BC (2009) Bayesian analysis of radiocarbon dates. Radiocarbon 51:337-360 Reimer PJ, Bard E, Bayliss A, Beck JW, Blackwell PG, Ramsey BC, Grootes PM, Guilderson TP, Haflidason H, Hajdas I, Hatte C, Heaton TJ, Hoffmann DL, Hogg AG, Hughen KA, Kaiser KF, Kromer B, Manning SW, Niu M, Reimer RW Richards DA, Scott EM, Southon JR, Staff RA, Turney CSM, van der Plicht J (2013) IntCal13 and Marine13 radiocarbon Age calibration curves 0-50,000 years cal BP. Radiocarbon 55:1869-1887

Sawai Y, Nasu H (2005) A 4500-year record of emergence events at Onnetoh, Hokkaido, northern Japan, reconstructed using plant macrofossils. Mar Geol 217:49-65

Sawai Y, Shishikura M, Okamura Y, Takada K, Matsuura T, Aung TT, Komatsubara J, Fujii Y, Fujiwara O, Satake K, Kamataki T, Fujino S (2007) A study on paleotsunami using handy geoslicer in Sendai Plain (Sendai, Natori, Iwanuma, Watari, and Yamamoto), Miyagi, Japan. Ann Rep Act Fault Paleoearthquake Res 7:47-80

Sawai Y, Kamataki T, Shishikura M, Nasu H, Okamura Y, Satake K, Thomson KH, Matsumoto D, Fujii Y, Komatsubara J, Aung TT (2009) Aperiodic recurrence of geologically recorded tsunamis during the past 5500 years in eastern Hokkaido, Japan. J Geophys Res 114, B01319

Sawai Y, Namegaya Y, Okamura Y (2012) Challenges of anticipating the 2011 Tohoku earthquake and tsunami using coastal geology. Geophys Res Lett 39, L21309

Shennan I, Bruhn R, Barlow N, Good K, Hocking E (2014) Late Holocene great earthquakes in the eastern part of the Aleutian megathrust. Quat Sci Rev 84:86-97

Shishikura M, Sawai Y, Okamura Y, Komatsubara J, Aung TT, Ishiyama T, Fujiwara O, Fujino S (2007) Age and distribution of tsunami deposit in the Ishinomaki Plain, Northeastern Japan. Ann Rep Act Fault Paleoearthquake Res 7:31-46

Spiske M, Piepenbreier J, Benavente C, Bahlburg H (2013) Preservation potential of tsunami deposits on arid siliciclastic coasts. Earth-Sci Rev 126:58-73

Sugawara D, Goto K, Imamura F, Matsumoto H, Minoura K (2012) Assessing the magnitude of the 869 Jogan tsunami using sedimentary deposits: Prediction and consequence of the 2011 Tohoku-oki tsunami. Sed Geol 282:14-26

Switzer AD, Jones BG (2008) Large-scale washover sedimentation in a freshwater lagoon from the southeast Australian coast: sea-level change, tsunami or exceptionally large storm? The Holocene 18:787-803

Szczucinski W (2012) The post-depositional changes of the onshore 2004 tsunami deposits on the Andaman Sea coast of Thailand. Nat Hazards 60:115-133

Tappin DR, Grilli ST, Harris JC, Geller RJ, Masterlark T, Kirby JT, Shi F, Ma G, Thingbaijam KKS, Mai PM (2014) Did a submarine landslide contribute to the 2011 Tohoku tsunami? Marine Geol 357:344-361

The Headquarters for Earthquake Research Promotion (2006) Research report of high-priority observation and survey on miyagi-oki earthquakes, 2005 fiscal year. The Headquarters for Earthquake Research Promotion, Tokyo

The Headquarters for Earthquake Research Promotion (2007) Research report of high-priority observation and survey on miyagi-oki earthquakes, 2006 fiscal year. The Headquarters for Earthquake Research Promotion, Tokyo

The Headquarters for Earthquake Research Promotion (2008) Research report of high-priority observation and survey on miyagi-oki earthquakes, 2007 fiscal year. The Headquarters for Earthquake Research Promotion, Tokyo

The Headquarters for Earthquake Research Promotion (2009) Research report of high-priority observation and survey on miyagi-oki earthquakes, 2008 fiscal year. The Headquarters for Earthquake Research Promotion, Tokyo

The Headquarters for Earthquake Research Promotion (2010) Research report of high-priority observation and survey on miyagi-oki earthquakes, 2009 fiscal year. The Headquarters for Earthquake Research Promotion, Tokyo

Torii K, Haraguchi T, Imaizumi T, Miyauchi T, Shimazaki K (2007) Survey of tsunami deposits at Sanriku coast, North East Japan. In: Proceedings of Japan society of engineering geology 2007. Osaka City University, Osaka, 11-12 October 2007

Tsuji Y, Ueda K (1995) Evaluation of A.D. 1611 Keicho, A.D. 1677 Enpou, A.D. 1763 Houreki, A.D. 1793 Kansei, and A.D. 1856 Ansei Sanriku tsunamis. Histo Earthq 11:75-106

Unohana M, Ota T (1988) Disaster records of Meiji Sanriku tsunami by Soshin Yamana. Res Rep Tsunami Disaster Control Center Tohoku Univ 5:57-379

Utsu T (2004) Catalog of damaging earthquakes in the world (through 2002), Tokyo. http://iisee.kenken.go.jp/utsu/index_eng.html. Accessed 24 December 2014.
Watanabe H (1998) Comprehensive list of tsunamis to hit the Japanese Islands 2nd edn. University of Tokyo Press, Tokyo

Witter RC, Kelsey HM, Hemphill-Haley E (2003) Great Cascadia earthquakes and tsunamis of the past 6700 years, Coquille River estuary, southern coastal Oregon. Geol Soc Am Bull 115:1289-1306

Yoshida T, Ohsawa A, Katada M (1984) Geological Map of Japan 1:200,000. Geological Survey of Japan, Tsukuba, Morioka

\section{Submit your manuscript to a SpringerOpen ${ }^{\odot}$ journal and benefit from:}

- Convenient online submission

Rigorous peer review

- Immediate publication on acceptance

- Open access: articles freely available online

- High visibility within the field

- Retaining the copyright to your article

Submit your next manuscript at springeropen.com 